\title{
AZ INTEGRÁCIÓ MUTATÓI ÉS ESÉLYKÜLÖNBSÉGEI A MAGYARORSZÁGON ÉLŐ BEVÁNDORLÓK KÖRÉBEN
}

\section{Gödri Irén}

\section{ÖSSZEFOGLALÓ}

A tanulmány a Magyarországon élő bevándorlók integrációs helyzetét vizsgálja a 2011-es népszámlálás adatai alapján, különös tekintettel a munkaerő-piaci integrációjukra. Külön kezeli a külföldi állampolgárokat és a külföldi születésüeket, rávilágítva a különböző származási csoportok heterogenitására. A zaragozai indikátorok alapján általános áttekintést nyújt a bevándorlók integrációs helyzetéről a főbb területeken (munkaerőpiac, oktatás, egészségi állapot, lakásviszonyok). Ezt követően részletesen elemzi a munkaerő-piaci integráció alapvető mutatóit (foglalkoztatottság, munkanélküliség, túlképzettség, önfoglalkoztatás) a bevándorlók egyes társadalmi-demográfiai és származási csoportjaiban, majd többváltozós elemzéssel vizsgálja a foglalkoztatottság és a túlképzettség esélyét befolyásoló tényezőket. Fontos megállapítása, hogy a Magyarországon élő bevándorlók magasabb foglalkoztatottsága elsősorban összetételüknek és területi elhelyezkedésüknek köszönhető, ugyanakkor származási országok és érkezési idő szerinti jelentős eltérések, valamint nemek közötti esélykülönbségek is kimutathatók. A magyar állampolgárság megszerzése, a magyar nemzetiség és anyanyelv, illetve a magyar nyelv elsajátítása növeli a nők foglalkoztatottsági esélyét, és mindkét nem esetében csökkenti a túlképzettség esélyét.

Tárgyszavak: bevándorlás, integráció, zaragozai indikátorok, foglalkoztatottság, túlképzettség

Gödri Irén, KSH Népességtudományi Kutatóintézet

E-mail:godri@demografia.hu 


\section{BEVEZETÉS}

A népesség demográfiai öregedése és különösen a munkavállalási korúak arányának csökkenése számos európai országban felveti a munkaerőhiány pótlásának szükségességét. Az elörejelzések szerint a folyamat - a várható élettartam növekedése és a tartósan alacsony termékenység következtében - a jövőben is folytatódik, ami hosszú távon (2050-ig) az EU-n belül a korösszetétel drámai átalakulását, a munkaerő-kínálat további csökkenését és az időskori függőségi ráta megkétszereződését eredményezi (European Union 2014). Mindez nemcsak a gazdasági növekedés, hanem a különböző társadalmi intézmények és állami ellátórendszerek fenntarthatóságát is megkérdőjelezi, és várhatóan számos munkaerő-piaci, szociális és költségvetési problémához vezet.

Mivel a jelenlegi tendenciák mellett a népesség fogyása és öregedése elkerülhetetlen, különböző elemzések a bevándorlásban látják - legalábbis rövid és középtávon - a lehetséges megoldást, kiemelve annak a munkaerőpótlásban, az időskori függőségi ráta mérséklésében, a nyugdijrendszer fenntarthatóságában, illetve a gazdasági növekedésben játszott szerepét (UNPD 2000, Espenshade 2001, van Nimwegen - van der Erf 2010, Gesano Strozza 2011). Ugyanakkor arra is rávilágítanak, hogy a népesség öregedéséből fakadó problémákra, illetve gazdasági kihívásokra az ún. helyettesítő migráció nem jelent hosszú távú megoldást. Az öregedési folyamat megállításához ugyanis folyamatos, nagymértékủ és exponenciálisan növekvő bevándorlásra lenne szükség (lévén, hogy a bevándorlók maguk is öregszenek), ami viszont gyökeresen megváltoztatja a befogadó ország népességének etnikai, társadalmi, kulturális összetételét (Lesthaeghe 2000, Coleman 2008, Saczuk 2013, Demény 2016, Murphy 2016).

A munkavállalási korú népesség létszámbeli pótlása ugyanakkor önmagában rövid távon sem feltétlenül jelent megoldást, amennyiben nem az adott ország munkaerő-piaci igényeihez igazodó, megfelelő képzettséggel, szaktudással rendelkező és a munkaerő-piacon elhelyezkedni tudó migráns népesség befogadásáról van szó. Bár a korösszetételt átmenetileg javítja, a gazdasági hatásokat viszont nem az aktív korúak száma, illetve az abból

\footnotetext{
'Az elöreszámitások a zéró migrációs egyenleggel számoló forgatókönyv esetén a munkavállalási korú (15-64 éves) népesség 11,7 milliós csökkenését prognosztizálták 2013 és 2020 között az Európai Unió 28 tagországában (OECD/ European Union 2014).

${ }^{2}$ A helyettesitő migráció (replacement migration) a bevándorlásnak az a szintje, amely ahhoz szükséges, hogy a népességfogyást, az aktív korú népesség csökkenését, valamint összességében a népesség öregedését ellensúlyozza (UNPD 2000).
} 
számolt (demográfiai) függőségi ráta határozza meg, hanem a ténylegesen foglalkoztatottak száma, illetve a nem dolgozókhoz viszonyított aránya, azaz a gazdasági függőségi ráta (lásd erről: Szigel 2016). A bevándorlás pozitív gazdasági hatásai tehát csak a bevándorlók sikeres munkaerő-piaci integrációja esetén várhatók.

A bevándorlók munkaerő-piaci mutatói azonban az európai országok többségében összességében rosszabbak, mint a honos népességé: alacsonyabb foglalkoztatási ráta, magasabb munkanélküliségi ráta, valamint a foglalkoztatottak körében a határozott időre szóló munkaszerződéssel dolgozók és a túlképzettek nagyobb aránya jellemzi mind a külföldi állampolgárokat, mind a külföldi születésủeket, illetve a fogadó országokban született leszármazottaikat (European Union 2011, OECD/European Union 2015, Eurostat 2016). Főként a kevésbé fejlett harmadik országokból származók - és ezen belül is föként a nők - munkaerőpiaci helyzete rosszabb, mint a fogadó népességé (miközben az EU-tagállamokból származók foglalkoztatottsága sok esetben jobb, mint a helyieké, noha a túlképzettség az ő esetükben is gyakori). A migráns népesség átlagosnál alacsonyabb munkaerő-piaci részvétele (különösen a nők esetében) számos fogadó országban további „függőséget” teremt (Coleman 2004), tovább terhelve az adott ország szociális ellátórendszerét.

A munkaerőhiány kezelésére a bevándorlás mellett természetesen egyéb megoldási lehetőségek is felmerülnek, mint például a munkaerő-tartalékok mozgósitása (azaz a foglalkoztatás növelése ${ }^{3}$ ), a nyugdijkorhatár emelése vagy a termelékenység fokozása. ${ }^{4}$ A foglalkoztatás növelése nemcsak a honos népesség - elsősorban a nők, a fiatal (15-24 éves) és az idősebb (55-64 éves) korcsoportok - esetében fontos célkitűzés, hanem a már letelepedett bevándorlók, illetve leszármazottaik esetében is (OECD/European Union 2014). Ez utóbbi csoportok munkaerő-piaci integrációja - a várható gazdasági hatások mellett - azért is fontos, hogy gazdasági leszakadásuk, és az ezzel járó társadalmi (és gyakran területi) szegregációjuk elkerülhető legyen. Noha a bevándorlásnak a demográfiai trendek ellensúlyozásában játszott szerepe vitatott, abban egyetértés van, hogy a bevándorlók társadalmi és gazdasági integrációja elengedhetetlen.

\footnotetext{
${ }^{3}$ Az Európa 2020 stratégia célkitüzései közt szerepel, hogy 2020-ra az EU egészét tekintve a 20-64 évesek körében a foglalkoztatottság aránya elérje a 75\%-ot. 2015-ben ez a mutató 70,6\% volt a honos népesség, 73,4\% a más EU-tagállam állampolgárai és 56,7\% a nem EU-s állampolgárok körben (Eurostat 2016).

${ }^{4}$ Az EU-n belüli mobilitás elősegitése is fontos lépés a potenciális munkaerő jobb felhasználása érdekében (noha ez a kibocsátó országok munkaerő-piacának bizonyos szegmenseiben gyakran munkaerőhiányt eredményez).
} 
Tanulmányunkban a Magyarországon élő bevándorlók integrációs helyzetét vizsgáljuk a 2011-es népszámlálás adatai alapján, különös tekintettel a munkaerőpiaci integrációjukra. Első lépésben arra keresünk választ, hogy a föbb integrációs mutatók alapján a bevándorlók - és főként a harmadik országból származók - helyzete mennyire tér el a hazai népességétől. A bevándorlók beazonositásához kétféle megközelítést is alkalmazunk: külön vizsgáljuk a külföldi állampolgárokat és a külföldi születésüeket, kitérve e két népesség sajátosságaira. Ezt követően részletesen is áttekintjük a munkaerő-piaci integráció alapvető mutatóit a bevándorlók egyes társadalmi-demográfiai és származási csoportjaiban, majd többváltozós elemzéssel a foglalkoztatottság és a túlképzettség esélyét befolyásoló tényezőket vizsgáljuk. Arra próbálunk választ találni, hogy a bevándorlók munkaerő-piaci helyzete mennyiben köszönhető sajátos összetételüknek, illetve az összetétel hatását kiszürve milyen szerepe van a származási országnak, az érkezés óta eltelt időnek, a magyar állampolgárság megszerzésének, a nemzetiségnek, valamint a magyar nyelv ismeretének. Az adatok elemzése előtt röviden áttekintjük az integráció fogalmának elméleti megközelítéseit, a föbb integrációs területeket és mutatókat, valamint a vizsgált migráns népesség összetételének főbb sajátosságait.

\section{AZ INTEGRÁCIÓ FOGALMÁNAK ELMÉLETI MEGKÖZELÍTÉSEI}

A bevándorlók beilleszkedésének vizsgálatában különböző elméleti megközelítésekkel és modellekkel találkozhatunk. A legkorábbi a Park (1928) nevéhez kötődő asszimilációs modell, amely szerint a bevándorlók (etnikai kisebbségek) beolvadása a többségi társadalomba egy lineáris és visszafordíthatatlan folyamat, és elkerülhetetlen következménye a különböző etnikai csoportok találkozásának. Ez a megközelítés arra a feltételezésre épült, hogy a fogadó társadalomra egy domináns többségi kultúra jellemző, amelybe a bevándorlók - nyelvük és kulturális szokásaik feladásával - előbbutóbb beleolvadnak. A '60-as évek elején Gordon (1964) felismerte, hogy az asszimilációs folyamat különböző szakaszokból áll, és a kulturális asszimiláció (a fogadó társadalom kulturális mintáinak átvétele) mellett megkülönböztette a strukturális asszimilációt (a fogadó társadalom intézményeibe és társadalmi struktúráiba való beépülést), valamint az azonosulási asszimilációt (a többségi társadalommal való azonosulást). Ezek közül a strukturális asszimilációt tartotta 
a folyamat katalizátorának: úgy vélte, ha ez bekövetkezik, akkor a többi szakasz is végbemegy, és elkerülhetetlen a teljes beolvadás. ${ }^{5}$

Az amerikai bevándorlás kapcsán megfogalmazott asszimilációs modell azonban az amerikai társadalom pluralizálódása következtében egyre kevésbé állta meg a helyét. Az általa leírt - a többségi társadalom kultúrájának, nyelvének, életmódjának átvételével járó - akkulturációs folyamat valójában a fehér, protestáns, angolszász gyökerü középosztálybeli népesség kulturális mintáinak átvételét feltételezte (anglo-konformitás), holott ez a „többségi” csoport egyre kisebb szeletet jelentett az etnikailag sokszínű társadalomban. ${ }^{6}$ Gordon szerint azonban inkább a strukturális, semmint a kulturális pluralizmus volt jellemző: az amerikai társadalmat olyan etnikai „kisközösségek” alkották, amelyek ugyan etnikai vonalak mentén szerveződtek, de kulturális sajátosságaikat egyre inkább elveszítették (Gordon 1964).

Ennek ellenére a különböző vizsgálatok azt állapították meg, hogy az etnikai csoportok közötti különbségek generációkon keresztül tartósnak bizonyultak, az iskolai és a foglalkozási mobilitást tekintve a hátrányok nem csökkentek, hanem újratermelődtek (Zhou 1997). A „második generáció hanyatlása” (Gans 1992) - ami arra utal, hogy a bevándorlók gyermekei gyakran a szüleikhez képest is rosszabb helyzetben vannak - főként a szegény, iskolázatlan és sötét bőrü bevándorló csoportok esetében volt megfigyelhető. Mindez megkérdőjelezte a lineáris folyamatként leírt asszimilációs modell általános érvényességét. Ugyanakkor többen azt feltételezték, hogy a különböző kimeneteleket csupán az asszimilációs folyamat eltérő sebessége magyarázza, amelyet a bevándorlók jellemzői (főként az emberi tőkéje), területi elhelyezkedésük, az adott etnikai csoport mérete, illetve a bevándorlás intenzitása határoz meg (Alba - Nee 1997). Arra is rámutattak, hogy míg a nyelvi akkulturáció többnyire egyirányú, addig más területeken (például a népi konyhákat tekintve) a különböző kultúrák kölcsönösen hatással vannak egymásra.

A kulturális és etnikai pluralizmus eszméinek terjedésével az egyetlen kimenetelt feltételező asszimilációs modell helyét átvették a beilleszkedési folyamat több lehetséges kimenetelével számoló integrációs modellek.

\footnotetext{
${ }^{5}$ A teljes asszimiláció többnyire nem a bevándorlók első, hanem inkább a második vagy harmadik generációjánál következik be, de arra is van példa, hogy éppen ez utóbbiak térnek vissza a bevándorló szüleik/nagyszüleik etnikai, kulturális gyökereihez.

${ }^{6}$ Gordon (1964) az asszimilációs folyamat kimenetelének alternatív lehetőségeként az 1910-es években megjelenő olvasztótége/y-mode/lt is megemlíti. Ez a modell arra a feltételezésre épült, hogy a különböző etnikai csoportok találkozása során ezek kölcsönös egymásra hatása, összeolvadása révén egy „új egység” jön létre.
} 
Felismerték, hogy a fogadó társadalom gazdasági, társadalmi, etnikai rétegzettsége, kulturális sokszínüsége különböző beilleszkedési mintákat tesz lehetővé. Míg az asszimiláció a bevándorlók egyirányú alkalmazkodását feltételezi, az integráció kulturális szempontból kétirányú folyamat, mely során a bevándorlók úgy válnak a fogadó társadalom tagjává, hogy közben maguk is alakítják annak kulturális arculatát, megőrizve ugyanakkor saját etnikai, kulturális identitásukat.

A strukturalista szemléletmód - amely a fogadó társadalom strukturális rétegzettségét és az ebből fakadó egyenlőtlenségeket hangsúlyozza - szintén megkérdőjelezi az asszimilációs modell alkalmazhatóságát. Eszerint a bevándorlók beilleszkedése elsősorban a fogadó társadalom gazdasági, társadalmi struktúráitól, valamint az etnikai hierarchiáktól függ, amelyek behatárolják az egyes csoportok különböző erőforrásokhoz (munkalehetőség, lakás, oktatás) való hozzáférését (Barth - Noel 1972). A beilleszkedés „sikeressége”, illetve „,haszna” a bevándorlók számára azon is múlik, hogy a társadalom, illetve a munkaerőpiac melyik szegmensébe integrálódnak (Portes - Sensenbrenner 1993, Zhou 1997). A fogadó ország szegmentált munkaerő-piaca gyakran azt eredményezi, hogy a munkaintenzív, képzettséget nem igénylő, mobilitási lehetőség nélküli és bizonytalan állásokkal jellemzett másodlagos szektorban van kereslet a bevándorlók munkája iránt (Piore 1979), tehát esélyük sincs arra, hogy a fogadó társadalom középosztályába integrálódjanak. A saját etnikai közösség jelenléte a befogadó országban ugyanakkor a többségi társadalomtól független integrációs lehetőségeket kínál a bevándorlók számára - akár munkaerő-piaci, akár társadalmi, kulturális szempontból (Portes - Sensenbrenner 1993, Turner Bonacich 2001, Portes - Manning 2005). ${ }^{\text {? }}$

Az akkulturáció és a gazdasági adaptáció irányát is figyelembe véve a szegmentált asszimiláció modellje a beilleszkedés különböző mintázatait tárja fel a második generációs migránsok körében, attól függően, hogy a középosztályba vagy az ún. „underclass”-ba integrálódnak-e, illetve hogy bekövetkezik-e akkulturáció vagy megőrzik a saját etnikai közösségük értékeit és a szolidaritást (Portes - Zhou 1993). A bevándorlók letelepedési mintáit vizsgálva Portes és Böröcz (1989) elemzése is jól szemlélteti, hogy a kibocsátó ország elhagyásának körülményei, a bevándorlók korábbi (kibocsátó országbeli) osztályhelyzete, valamint a célországban tapasztalt fogadókészség nagyon eltérő beilleszkedési mintákat eredményez. Mindez egyfelől rávilágít arra, hogy az egyenes vonalú

\footnotetext{
${ }^{7}$ Mind a közvetítő kisebbségek elmélete, mind az etnikai vállalkozások modellje kiemeli a bevándorlás során szerzett negatív tapasztalatokat, amelyek következtében erős csoporton belüli szolidaritás alakul ki az adott etnikai csoportban.
} 
folyamatként értelmezett asszimiláció modellje elfedte a különféle etnikai csoportok sajátos beilleszkedési útjai közötti különbségeket. Másfelől viszont arra is felhívja a figyelmet, hogy a beilleszkedés különböző kimeneteleit a fogadó országban töltött idő hossza mellett a bevándorlók egyéni jellemzői (iskolai végzettsége, szakképzettsége, nyelvismerete, életkora, születési helye, kapcsolati tőkéje) és migrációs motivációi, valamint strukturális tényezők (a letelepedési hely társadalmi és gazdasági struktúrái, az etnikai csoporton belüli szolidaritás, a családi háttér) is meghatározzák. Különösen az egyéni jellemzők és a strukturális tényezők közötti interakciónak van jelentős szerepe (Zhou 1997).

A hagyományos megközelítés szerint - amely a fogadó társadalom alsóbb rétegeibe belépő amerikai bevándorlók vizsgálatára épült - idővel csökkennek az egyenlőtlenségek, és a bevándorlók társadalmi-gazdasági helyzete (a képzettségi, munkaerő-piaci, foglalkozási, jövedelmi mutatókat tekintve) közelít a fogadó népesség átlagához. A társadalmi-gazdasági integráció sikerességéről is többnyire akkor beszélünk, ha a különböző területeken - munkaerőpiac, oktatás, lakhatási körülmények stb. - a bevándorlók mutatói nem rosszabbak, mint a fogadó társadalomé. Míg azonban az asszimilációs modell szerint a strukturális beépülést kulturális és azonosulási asszimiláció is követi, az integrációs modell szerint ez nem feltétlenül jár együtt a bevándorlók kulturális és etnikai identitásának feladásával. A többféle kimenetellel számoló integrációs modell ugyanakkor a társadalmi-gazdasági integráció egy másik értelmezését is lehetővé teszi: a bevándorlók különböző csoportjainak a mutatóit nem a többségi társadalom egészéhez, hanem annak a hasonló hátérrel rendelkező csoportjaihoz hasonlítja, ezáltal az összetétel hatását kiszúrve határozza meg a bevándorlók helyzetét a fogadó társadalmon belül.

\section{A BEVÁNDORLÓK INTEGRÁCIÓJÁNAK FÖBB TERÜLETEI ÉS MUTATÓI}

A bevándorlók integrációja a fogadó társadalomba tehát egy komplex, többdimenziós folyamatként értelmezhető, amely során a bevándorlók beépülnek a fogadó társadalom - vagy e társadalom különböző szegmenseinek - gazdasági, társadalmi, politikai struktúráiba, és alkalmazkodnak annak kulturális, társadalmi érték- és normarendszeréhez. Többnyire a szociális-gazdasági, a kulturális és a jogi-politikai dimenziók jelennek meg az integráció vizsgálatában, valamint - tekintettel a fogadókészség fontosságára - a fogadó társadalom részéről megnyilvánuló attitüdök is figyelmet kapnak (Entzinger - Biezeveld 2003). 
A bevándorlók - elsősorban a legálisan tartózkodó harmadik országbeli állampolgárok - integrációja EU-s szinten és az egyes tagállamokban is (különösen a hagyományos befogadó országokban) a migrációs politika fontos célkitüzése. Az Európai Bizottság által meghatározott és a Bel- és Igazságügyi Tanács által 2004-ben elfogadott közös integrációs alape/vek már az elején leszögezik, hogy az integráció egy dinamikus, kétirányú folyamat, amely a bevándorlók és a fogadó társadalom kölcsönös alkalmazkodását feltételezi, ugyanakkor az Európai Unió alapvető értékeinek tiszteletét is magába foglalja. A svéd elnökség 2009-es malmöi konferenciáján - a közös integrációs alapelvekből kiindulva - meghatározták a négy alapvető integrációs területet, valamint a hozzájuk tartozó indikátorokat.9 A 2010 áprilisában elfogadott Zaragozai Nyilatkozat ${ }^{10}$ tartalmazza ezeket az indikátorokat - innen ered a „zaragozai indikátorok” elnevezés. A nyilatkozatban négy alapvető szakpolitikai területen - a foglalkoztatás, az oktatás, a szociális helyzet, valamint az aktív állampolgárság - összesen 14 alapindikátor szerepel (lásd 1. táblázat). Ezek mellett további kiegészítő/fejlesztendő indikátorokat is felsorolnak, amelyekről azonban - noha a tagállamok zöme fontosnak tekinti - nem állnak rendelkezésre összehasonlítható adatok.

A zaragozai indikátorok relevanciáját az Európai Bizottság 2011-es pilot vizsgálata (European Comission 2011), majd egy 2012-2013-as projektje is megerősitette (Huddleston et al. 2013). Ez utóbbi ugyanakkor a meglévőkhöz egy újabb integrációs terület - az ún. befogadó társadalom (Welcoming Society) - hozzáadását is felvetette (ide sorolva a diszkriminációs tapasztalat, a közintézményekbe vetett bizalom, valamint a befogadó társadalomhoz való tartozás érzetének mutatóit). Emellett a meglévő területeken is további - a Zaragozai Nyilatkozatban a kiegészitő indikátorok közt sem szereplő indikátorokat javasolt (lásd az 1. táblázatban dőlt betűvel jelölve). Az alábbiakban röviden áttekintjük az egyes integrációs területeket és a hozzájuk tartozó indikátorokat.

\footnotetext{
${ }^{8} \mathrm{http}: / /$ www.eesc.europa.eu/resources/docs/common-basic-principles_en.pdf (Letöltve: 2016. 05. 11.)

${ }^{9}$ Az alapindikátorok kiválasztásánál az is szempont volt, hogy időbeli és országok közötti összehasonlitásra alkalmas, jó minőségủ adatok álljanak rendelkezésre az egyes tagállamokban.

${ }^{10} \mathrm{https} / /$ ec.europa.eu/migrant-integration/librarydoc/declaration-of-the-european-ministerial-conference-onintegration-zaragoza-15-16-april-2010 (Letöltve: 2016. 05. 12.)
} 
1. táblázat: A bevándorlók integrációs mutatói a 2010-es Zaragozai Nyilatkozat alapján* Indicators of immigrants' integration based on the Zaragoza Declaration adopted in 2010

\begin{tabular}{|c|c|c|}
\hline Integrációs terület & Alapvető indikátorok & Kiegészítő (javasolt) indikátorok \\
\hline Foglalkoztatás & $\begin{array}{l}\text { - foglalkoztatási ráta } \\
\text { • munkanélküliségi ráta } \\
\text { • aktivitási arány }\end{array}$ & $\begin{array}{l}\text { - túlképzettek aránya } \\
\text { - vállalkozók, önfoglalkoztatók } \\
\text { aránya } \\
\text { - tartós munkanélküliség } \\
\text { - nem szándékos inaktivitás }\end{array}$ \\
\hline Oktatás & $\begin{array}{l}\text { - legmagasabb iskolai végzettség } \\
\text { (a különböző végzettségűek aránya) } \\
\text { • az olvasásban, matematikában és } \\
\text { természettudományokban gyengén } \\
\text { teljesítő } 15 \text { évesek aránya } \\
\text { - a felsőfokú végzettségűek aránya } \\
\text { a 30-34 éves korcsoportban } \\
\text { - korai iskolaelhagyók aránya } \\
\text { (iskolai és képzési lemorzsolódás) }\end{array}$ & $\begin{array}{l}\text { - nyelvtudás, nyelvhasználat } \\
\text { (a befogadó ország nyelvének } \\
\text { ismerete) } \\
\text { - oktatásban/képzésben nem } \\
\text { részesüló és nem is foglalkoztatott } \\
\text { fiatalok aránya }\end{array}$ \\
\hline Szociális helyzet & $\begin{array}{l}\text { • medián nettó jövedelem (a } \\
\text { bevándorlók medián nettó } \\
\text { jövedelme a teljes népesség medián } \\
\text { nettó jövedelmének arányában) } \\
\text { • a szegénységi küszöb alatt élők } \\
\text { aránya (a medián nettó jövedelem } \\
60 \% \text {-a alatti nettó jövedelműek } \\
\text { aránya) } \\
\text { • saját egészségi állapot megítélése } \\
\text { - ingatlantulajdonosok és } \\
\text { ingatlannal nem rendelkezők } \\
\text { aránya a bevándorlók közt és a } \\
\text { teljes népességben }\end{array}$ & $\begin{array}{l}\text { - diszkriminációs tapasztalat } \\
\text { - a közintézményekbe vetett bizalom } \\
\text { - a befogadó társadalomhoz való } \\
\text { tartozás érzete } \\
\text { - túlzsúfolt lakásban lakók }\end{array}$ \\
\hline Aktív állampolgárság & $\begin{array}{l}\text { • az állampolgárságot szerzett } \\
\text { bevándorlók aránya } \\
\text { • az állandó vagy huzamos } \\
\text { tartózkodási engedéllyel rendelkező } \\
\text { bevándorlók aránya } \\
\text { • a bevándorlók aránya a választott } \\
\text { képviselők között }\end{array}$ & $\begin{array}{l}\text { • szavazási részvétel a szavazásra } \\
\text { jogosultak körében (választójog } \\
\text { gyakorlása) }\end{array}$ \\
\hline
\end{tabular}




\section{Foglalkoztatás, munkaerő-piaci integráció}

A munkaerő-piaci integráció a bevándorlók beilleszkedési folyamatának kulcseleme, amely a társadalmi és a kulturális integrációt is elősegitheti. Leggyakrabban vizsgált mutatói a foglalkoztatási ráta, a munkanélküliségi ráta és az aktivitási arány. Az alacsony foglalkoztatottság adódhat abból, hogy a bevándorlók egy része be sem lép a munkaerő-piacra (azaz nem is próbál munkát találni), tehát az aktivitási arány is alacsony körükben; ha viszont magas munkanélküliségi ráta társul hozzá, az azt mutatja, hogy a munkaerő-piacra belépők közül sokan nem tudnak elhelyezkedni.

A sikeres integráció azonban nemcsak a munkához való hozzáférést, hanem a bevándorlók emberi tőkéjének hasznosulását is jelenti, ezért a foglalkoztatottak esetében további fontos mutató a túlképzettség, azaz a felsőfokú végzettségü foglalkoztatottak körében az alacsony vagy közepes képzettséget igénylő munkát végzők aránya.

A szegmentált munkaerőpiac ugyanakkor különböző integrációs lehetőségeket jelent. A bevándorlók gyakran az alacsony bérekkel, kedvezőtlen munkafeltételekkel, nagyfokú bizonytalansággal és a mobilitási lehetőségek hiányával jellemzett szekunder szektorban találnak munkát - a foglalkoztatottság önmagában erről nem nyújt információt." További lehetőségként az önfoglalkoztatás, illetve az etnikai vállalkozásokban való foglalkoztatottság jelenik meg. Ezek a sikeres gazdasági integráció, vagy éppen a munkanélküliség, illetve a diszkrimináció elkerülésének útjai is lehetnek egyben. Az etnikai vállalkozások az alacsonyabb képzettségű és a fogadó ország nyelvét nem beszélő migránsok számára is biztosítanak megélhetést, sőt gyakran előrelépési lehetőséget is.

A munkanélküli és egyéb inaktív csoportok esetében a munkaerő-piaci kirekesztődés fontos mutatója a tartós munkanélküliség előfordulása (azok aránya a munkanélkülieken belül, akik legalább egy éve állás nélkül vannak), valamint a nem szándékos inaktivitás (ami az inaktív csoporton belül azok arányát jelenti, akik bár készek lennének munkába állni, de feladták az aktív munkakeresést, tehát nem jelennek meg munkanélküliként) (OECD/European Union 2015).

\footnotetext{
" Ennek megragadására javasolt indikátorok: az állami szektorban foglalkoztatottak aránya, a határozott időre szóló munkaszerződéssel foglalkoztatottak aránya, a szándékuk ellenére részmunkaidőben foglalkoztatottak aránya. Ezek a mutatók a népszámlálási adatok alapján azonban nem vizsgálhatók.
} 


\section{Oktatás}

Az oktatás - legyen szó akár különféle képzésekröl, akár nyelvoktatásról - fontos terület a bevándorlók integrációjának elősegítése szempontjából. A bevándorlók iskolai végzettsége, szakképzettsége, nyelvismerete nagymértékben meghatározza a foglalkoztatási esélyeiket, valamint az integráció egyéb területeire is hatással van. Az oktatás területén megjelölt négy alapvető zaragozai indikátor azonban elsősorban a második generációs bevándorlók - vagy a gyermekként érkezők - esetében értelmezhető integrációs mutatóként. Az első generációs, és már felnőttként érkező bevándorlók iskolai végzettsége inkább a munkaerőpiac és a bevándorlás-politika szelekciós hatásait tükrözi, noha a legmagasabb iskolai végzettség megszerzése olykor már a fogadó országban történik. A bevándorlók meglévő (külföldön szerzett) végzettségének elismerése gyakran nehézségekbe ütközik, megtérülése a munkaerő-piacon többnyire rosszabb, nagyobb a leértékelődésének kockázata.

A 30-34 éves korcsoportban a felsőfokú végzettségüek aránya az adott csoport várható versenyképességét jelzi. Erre az életkorra a legmagasabb iskolai végzettség megszerzése többnyire befejeződik. Az Európa 2020 stratégia oktatási célkitúzése, hogy 2020-ra EU-s szinten a 30-34 éves korcsoport 40\%-a (Magyarország esetében 30,3\%-a) felsőfokú végzettséggel rendelkezzen.

A korai iskolaelhagyók aránya a 18-24 éves korcsoportban azokat jelöli, akik legfeljebb általános iskolai végzettséggel rendelkeznek, ${ }^{12}$ és nem vesznek részt oktatásban vagy képzésben. Erre vonatkozóan az Európa 2020 stratégia mind EU-s szinten, mind Magyarország esetében 10\%-os arány elérését tủzte ki célul. Az oktatási rendszerből, illetve szakképzési programokból lemorzsolódók aránya a későbbi munkaerő-piaci érvényesülés nehézségeivel és nagyobb szegénységi kockázattal szembesülő népesség nagyságát vetíti előre.

A nyelvtudás, és ezen belül a befogadó ország nyelvének ismerete az erre vonatkozó összehasonlítható adatok hiánya miatt a kiegészítő indikátorok közt szerepelaZaragozai Nyilatkozatban, holott-mintaztaközösintegrációsalapelvek is leszögezik - a befogadó társadalom nyelvének (valamint történelmének és intézményeinek) alapfokú ismerete nélkülözhetetlen a beilleszkedéshez. A nyelvi kompetencia hiánya mind a munkaerő-piaci, mind a társadalmi beilleszkedés lehetőségeit behatárolja, különböző területeken diszkriminációhoz vezethet, és többnyire az állampolgárság megszerzésének is akadálya.

${ }^{12}$ Az oktatás egységes nemzetközi osztályozási rendszerében (ISCED) ez a 3-as szint alatti végzettséget jelenti, illetve a korábbi (ISCED 1997) osztályozási rendszer szerint a „3C short” kategóriába tartozókat is ide sorolták. 
Szintén a kirekesztődés mutatója az oktatásban/képzésben nem részesülő és nem is foglalkoztatott népesség aránya a különböző - főként fiatal korcsoportokban. Ezt gyakran éppen a nyelvtudás hiánya eredményezi, ami nemcsak a munkaerőpiachoz, de az oktatási rendszerhez való hozzáférést is korlátozza.

\section{Szociális helyzet ${ }^{13}$}

A szociális helyzet vonatkozásában négy különböző - noha egymástól nem teljesen független - alapindikátor szerepel, amelyek a bevándorlók jövedelemi helyzetét és az ehhez kapcsolódó szegénységi kockázatát, továbbá szubjektív egészségi állapotát, valamint ingatlantulajdonlását mérik. Az első kettő rendkivül fontos indikátor a társadalmi kirekesztődés szempontjából, ám értelmezésük csak az iskolai végzettség és foglalkozási helyzet, valamint a fogadó országban töltött idő figyelembevételével lehetséges. A népszámlálásban jövedelemre vonatkozó adat nem szerepel. A szubjektiv egészségi állapot, mint a jóllét mutatója, részben a jövedelmi helyzettől, de jelentős mértékben a korösszetételtől is függ. A népszámlálás alapján csak egy közelítő mutató - a tartós betegséggel és/vagy fogyatékossággal rendelkezők aránya - vizsgálható. Hasonlóképpen az ingatlannal rendelkezők aránya is függ az életkortól, valamint az érkezés óta eltelt idő hosszától. A lakáshelyzet fontos mutatója - noha csak a 2013-ban javasolt indikátorok közt szerepel - a túlzsúfolt lakásban élök aránya is, ami szintén függ a háztartás jövedelmi helyzetétől.

\section{Aktív állampolgárság}

Az aktív állampolgárság kapcsán három alapindikátor jelenik meg: a honositottak aránya, az állandó vagy huzamos tartózkodási engedéllyel rendelkezők aránya, valamint a bevándorlók aránya a választott képviselők között. A népszámlálás csak az állampolgárságra vonatkozóan tartalmaz adatot. A honositottak aránya többféle definícióval is előfordul a különböző vizsgálatokban: van, ahol az adott évben honosítottak arányát jelenti az év elején az országban tartózkodó külföldi állampolgárságú bevándorlókhoz képest (European Commission 2011), máshol

\footnotetext{
${ }^{13}$ Ez az integrációs terület (social inclusion) társadalmi befogadásként is szerepel a magyar anyagokban, ami viszont inkább a fogadó társadalom attitüdjére utal, holott főként a bevándorlók szociális helyzetét tükröző indikátorokról van szó. Ezért a Kováts (2013) által használt megnevezést alkalmazzuk.
} 
viszont a fogadó ország állampolgárságával rendelkező külföldi születésű népesség arányát az állampolgárságra jogosult külföldi születésűeken belül (OECD/European Union 2015). A népszámlálási adatok alapján csak ez utóbbi megközelítésben (és bizonyos korlátokkal) vizsgálható a honosítottak aránya. A jogosultságot a honosítási feltételrendszer szabályozza, amelyben az országban eltöltött idő fontos szempont, de az egyes bevándorló csoportok esetében eltérőek a követelmények. Az állampolgárság megszerzése tehát - bár fontos mérföldkő az integrációs folyamat során - az adott bevándorló csoportra jellemző integrációs szándék mellett a befogadó ország honosítási politikáját is tükrözi.

\section{AZ ADATOK FORRÁSA, A VIZSGÁLT NÉPESSÉG MEGHATÁROZÁSA}

A zaragozai alapindikátorok többségéhez az EU-s szinten harmonizált munkaerő-felmérések (EU-LFS), illetve a jövedelemre és életkörülményekre vonatkozó EU-SILC felmérések jelentik a fő adatforrást. Magyarországon azonban - a külföldi születésü, és főként a külföldi állampolgárságú népesség alacsony aránya, valamint egyenlőtlen területi megoszlása miatt - ezek a felmérések nem reprezentálják megfelelően a külföldi népességet,14 továbbá a mintába kerülő külföldiek alacsony elemszáma nem teszi lehetővé a részletesebb bontású elemzéseket. Ezzel szemben a legutóbbi népszámlálás az ország területén legalább egy évig tartózkodó külföldi állampolgárságú, illetve külföldi születésü népesség teljes körü keresztmetszeti adatbázisát jelenti, amely egyedülálló lehetőséget nyújt részletes elemzésekre. ${ }^{15} \mathrm{Az}$ integrációs mutatók jelentős része - főként a foglalkoztatás és az oktatás területén - vizsgálható a népszámlálási adatok alapján, és lehetőség van ezeknek a hazai népesség azonos időben és módon feltárt hasonló jellemzőivel való összehasonlítására is. ${ }^{16}$

\footnotetext{
${ }^{14}$ Ennek a problémának a kezelésére 2014. II. negyedévében a hazai munkaerő-felmérésben a harmadik országbeli állampolgárokra kiterjesztett mintadúsitást hajtottak végre az alapmintától független további 4000 cím felkeresésével (KSH 2015).

${ }^{15}$ A külföldi népesség összeirrásának sikeressége érdekében a népszámlálás során idegen nyelvü kérdőiveket is alkalmaztak: az internetes felületen angol nyelvű, az önkitöltésre is alkalmas papírkérdőívek esetében pedig a magyarországi nemzetiségek nyelvein kívül angol, francia, kínai és vietnámi nyelvű kérdőívek is rendelkezésre álltak. Az idegen nyelvű kérdőívek felhasználásának nagyságrendjéről azonban nincs információ.

${ }^{16}$ A népszámlálás azonban - mivel tízévente kerül rá sor - nem alkalmas az időbeli trendek bemutatására, csupán a nagyobb léptékű változások megragadását teszi lehetővé.
} 
Elemzésünk a 2011. évi népszámlálás adataira épül. A bevándorlók beazonosítása állampolgárság és születési hely alapján is lehetséges, e kétféle megközelítés azonban eltérő nagyságú és összetételü - egymást részben átfedő - migráns népességet eredményez. Az országban élő külföldi állampolgárok a bevándorolt népességnek csak egy részét jelentik, és főként az utóbbi években érkezetteket reprezentálják. Magyarországon, ahol a honosítási ráta magas, a külföldi állampolgárok száma alapján jelentősen alulbecsüljük a bevándorolt népességet. Ugyanakkor a külföldi állampolgárok közt szerepelnek azok is, akik Magyarországon, de külföldi állampolgárok gyermekeként születtek és (még) nem kaptak magyar állampolgárságot (tehát az ún. második generáció), valamint azok a magyarországi születésủek, akik a korábbi évtizedekben kivándoroltak, majd külföldi állampolgárságot szerezve később visszatértek Magyarországra (ők zömében kettős állampolgárok). A külföldön született népesség a bevándorlók tágabb csoportja, amely a régebben érkezett, már állampolgárságot szerzett bevándorlókat is tartalmazza. Magyarországon ebbe a csoportba tartoznak azok is, akik valamikor magyar állampolgárként, de az ország mai határain kívül születtek, és belső vándorlás vagy lakosságcsere során kerültek a mai területekre. Ez utóbbi egy nagyon idős, míg a külföldi állampolgárként szereplő második generációs bevándorlók egy nagyon fiatal korösszetételü csoport, így az integrációs mutatók szempontjából vizsgált 15-64 éves korcsoportban egyik sem jelenik meg. ${ }^{17}$

A föbb integrációs mutatókat mind a külföldi állampolgárságú, mind a külföldi születésű népesség esetében bemutatjuk - mindkét csoportnál külön a harmadik országból származókra is. A részletesebb elemzések - a foglalkoztatottság és a túlképzettség esélyét vizsgáló többváltozós modellek a külföldön született népességre vonatkoznak, figyelembe véve a magyar vagy külföldi állampolgárságot.

\footnotetext{
${ }^{17}$ Szintén a születési hely alapján azonosithatók be egyértelmủen azok az új bevándorlók is, akik a 2011-től életbe lépő egyszerüsített honositás következtében már magyar állampolgárként érkeztek, főként a szomszédos országokból. A 2011es népszámlálásban azonban ez a csoport még nem jelent meg nagy számban.
} 


\section{A BEVÁNDORLÓK SZÁMA ÉS ÖSSZETÉTELE}

A 2011. évi népszámlálás 143197 fő (csak) külföldi állampolgárságú és 88906 fő kettős (külföldi és magyar) állampolgárságú, valamint 383236 fő külföldi születésủ személyt számolt össze. A külföldi születésűek 65\%-a rendelkezett magyar állampolgársággal (is). Ugyanakkor a csak külföldi állampolgársággal rendelkezők 5\%-a, a kettős (külföldi és magyar) állampolgárok 29\%-a Magyarországon született.

A kettős állampolgárok csoportját a továbbiakban külön nem vizsgáljuk. ${ }^{18}$ A külföldi állampolgárok vizsgált csoportja a csak külföldi állampolgársággal rendelkező személyeket tartalmazza. A népszámlálások alapján a külföldi állampolgárok népességen belüli aránya 2001 és 2011 között 0,9\%-ról 1,4\%-ra, míg a külföldi születésűek aránya 2,9\%-ról 3,9\%-ra emelkedett. Ezek az arányok - bár néhány korcsoportban kissé magasabbak (a 20 és 34 év közöttiek több mint 2\%-a külföldi állampolgár, illetve a 40-44 évesek és a 65 év felettiek több mint 5\%-a külföldi születésű) - európai viszonylatban továbbra is alacsonynak számítanak.

A származási ország szerinti összetételüket tekintve mind a külföldi állampolgárok, mind a külföldi születésűek csoportjában a négy szomszédos ország - Románia, Ukrajna, Szerbia és Szlovákia - mellett Németország és Kína volt jelentősebb számban képviselve: a külföldi állampolgárok 64,5\%-a, a külföldön születettek 80\%-a ebből a hat országból származott. A bevándorlók integrációjának vizsgálata során fontos megkülönböztetni a másik EU-tagállamból, illetve a harmadik országból származók csoportját, mások ugyanis a tartózkodás, illetve a munkavállalás feltételei, és gyakran a két csoport helyzete jelentősen eltér. Magyarországon 2011-ben a külföldi állampolgárok 41\%-a, a külföldön születettek 31\%-a származott az EU27-en kivüli, ún. harmadik országból. Míg a harmadik országbeli állampolgárok több mint fele Európán kívüli (főként ázsiai) ország állampolgára volt, a harmadik országban születettek 54\%-a Ukrajnában vagy Szerbiában született (2. táblázat).

\footnotetext{
${ }^{18}$ Jelentős részük a külföldi születésủ népességben megjelenik. Annak, hogy a honosítottak közül kik tartották meg a korábbi állampolgárságukat is, vizsgálatunk szempontjából nincs jelentősége.
} 
2. táblázat: A külföldi állampolgárságú és a külföldi születésü népesség megoszlása származási ország szerint (\%)

Distribution of foreign citizens and foreign-born population by country of origin (\%)

\begin{tabular}{|c|c|c|c|c|c|c|}
\hline \multirow{2}{*}{$\begin{array}{l}\text { Állam- } \\
\text { polgárság } \\
\text { országa } \\
\text { / Születési } \\
\text { ország }\end{array}$} & \multicolumn{3}{|c|}{ Külföldi állampolgárok } & \multicolumn{3}{|c|}{ Külföldön született népesség } \\
\hline & $\begin{array}{l}\text { EU27 állam- } \\
\text { polgárok }\end{array}$ & $\begin{array}{c}\text { harmadik } \\
\text { országbeli } \\
\text { állam- } \\
\text { polgárok }\end{array}$ & együtt & $\begin{array}{l}\text { EU27-ben } \\
\text { született }\end{array}$ & $\begin{array}{c}\text { harmadik } \\
\text { országban } \\
\text { született }\end{array}$ & együtt \\
\hline Románia & 45,6 & & 26,9 & 67,0 & & 46,1 \\
\hline Szlovákia & 9,7 & & 5,8 & 12,6 & & 8,7 \\
\hline Németország & 20,1 & & 11,9 & 8,6 & & 5,9 \\
\hline többi EU15 & 20,3 & & 12,0 & 9,2 & & 6,4 \\
\hline többi EU27 & 4,3 & & 2,5 & 2,6 & & 2,6 \\
\hline Ukrajna & & 20,2 & 8,3 & & 29,5 & 9,2 \\
\hline Szerbia & & 13,2 & 5,4 & & 24,3 & 7,6 \\
\hline egyéb európai & & 14,3 & 5,8 & & 14,0 & 3,4 \\
\hline Kína & & 15,1 & 6,2 & & 7,3 & 2,3 \\
\hline egyéb ázsiai & & 22,9 & 9,4 & & 14,0 & 4,4 \\
\hline egyéb & & 14,3 & 5,8 & & 10,9 & 3,4 \\
\hline Összesen & 100,0 & 100,0 & 100,0 & 100,0 & 100,0 & 100,0 \\
\hline$N$ & 84582 & 58615 & 143197 & 263481 & 119755 & 383236 \\
\hline
\end{tabular}

Forrás: KSH, 2011. évi népszámlálás. Saját számítás.

A külföldön született népesség összességében is sokkal erőteljesebben koncentrálódik a négy szomszédos kibocsátó országra (72\%), mint a külföldi állampolgárságú népesség (46\%). Ez egyfelől annak köszönhető, hogy a szomszédos országokból érkezett bevándorlók nagyobb arányban szereznek magyar állampolgárságot, azaz „kilépnek” a külföldi állampolgár kategóriából, másfelől az újonnan érkezők összetételének változását is jelzi. Magyarország EU-csatlakozása óta az Európán kívüli származási országok köre kiszélesedett, a szomszédos országokból érkezők dominanciája egyre kevésbé érvényesül. ${ }^{19}$ A bevándorlók származási ország szerinti diverzifikálódását az is mutatja, hogy a két népszámlálás között a külföldi születésü népesség körében a születési ország szerinti csoportok száma 192-ről 218-ra emelkedett, a legalább 1000 fős

\footnotetext{
${ }^{19}$ Ugyanakkor az egyszerüsített honosítás 2011-es bevezetése óta a szomszédos országokból érkező bevándorlók jelentős része magyar állampolgárként érkezik (lásd erről: Gödri 2015).
} 
csoportoké 17-ről 32-re. Ezzel együtt a különböző állampolgárságok száma is nőtt, miközben a magyar nemzetiségüek aránya a külföldi születésű népességen belül csökkent (lásd a mellékletben: M1. táblázat).

Az integrációs mutatók értelmezéséhez fontos a bevándorlók társadalmidemográfiai összetételét és területi elhelyezkedését is figyelembe venni, ez ugyanis jelentősen különbözhet a fogadó népességétől. Ugyanakkor a bevándorlók maguk sem alkotnak homogén csoportot: születési országok szerint mind társadalmi-demográfiai összetételükben, mind érkezési idejük és területi elhelyezkedésük tekintetében jelentős heterogenitás figyelhető meg, ami nyilvánvalóan rányomja bélyegét az egyes származási csoportok integrációs mutatóira is.

A nemek aránya a 15-64 éves (az integráció kapcsán leginkább vizsgált) külföldi állampolgárok körében kiegyenlített, míg a külföldi születésűeknél enyhe női többlet (53\%) figyelhető meg, amely kissé meghaladja a teljes népességbeli női arányt (51\%). A külföldi állampolgárok a fogadó népességnél összességében fiatalabbak: az említett korcsoporton belül az átlagéletkoruk nem éri el a 38 évet (szemben a teljes népességre jellemző 40 évvel). A 15 és 64 év közötti külföldi születésü népesség átlagéletkora közel azonos a teljes népességével (noha a 65 év felettiek aránya számottevően nagyobb, a 15 év alattiaké pedig kisebb körükben). Az aktív korú népességen belül a 25-54 évesek, azaz a legjobb munkavállalási korúak aránya a külföldiek valamennyi csoportjában lényegesen nagyobb (68-70\% körüli), mint a teljes népességben (61\%).

A bevándorlók iskolai végzettség szerinti összetétele is eltér a hazai népességétől. Mivel ez az integrációs mutatók közt is szerepel, itt csak az érettségizettek és a felsőfokú végzettségüek arányát hasonlítjuk össze a megfelelő korú népességben. Látható, hogy míg a 18-64 éves magyarországi népesség 54\%-a rendelkezett legalább középiskolai érettségivel, a külföldi állampolgárok 63\%-a, a külföldi születésűek több mint kétharmada. A 25-64 évesek körében a felsőfokú végzettségüek aránya is számottevően nagyobb a bevándorlók mindkét csoportjában: 30\% körüli, míg a teljes népességben mindössze 21\%. Különösen magas a diplomások aránya a harmadik országból származók körében: 34\%, illetve 40\% (3. táblázat). Bár származási országok szerint jelentősek a különbségek, szinte valamennyi csoportban (a nagyon idős korösszetételű horvátországi születésűek kivételével) magasabb az iskolázottak aránya, mint a hazai népességben. 
3. táblázat: A 15-64 éves külföldi állampolgárságú, illetve külföldi születésü népesség társadalmidemográfiai összetétele a teljes népességgel összehasonlitva (\%)

Socio-demographic composition of foreign citizens and foreign-born population aged 15-64 compared to the total population (\%)

\begin{tabular}{|c|c|c|c|c|c|}
\hline $\begin{array}{l}\text { Társadalmi-demográfiai } \\
\text { összetétel }\end{array}$ & $\begin{array}{l}\text { Külföldi } \\
\text { állam- } \\
\text { polgárok }\end{array}$ & $\begin{array}{l}\text { Harmadik } \\
\text { országbeli } \\
\text { állam- } \\
\text { polgárok }\end{array}$ & $\begin{array}{l}\text { Külföldön } \\
\text { született } \\
\text { népesség }\end{array}$ & $\begin{array}{l}\text { Harmadik } \\
\text { országban } \\
\text { született } \\
\text { népesség }\end{array}$ & $\begin{array}{l}\text { Teljes } \\
\text { népesség }\end{array}$ \\
\hline \multicolumn{6}{|l|}{ Nem } \\
\hline férfi & 49,9 & 51,2 & 47,1 & 49,0 & 49,3 \\
\hline nő & 50,1 & 48,8 & 52,9 & 51,0 & 50,7 \\
\hline Összesen & 100,0 & 100,0 & 100,0 & 100,0 & 100,0 \\
\hline Átlagéletkor (év) & 37,7 & 36,9 & 39,7 & 38,9 & 40,0 \\
\hline \multicolumn{6}{|l|}{ Korcsoport } \\
\hline $15-24$ & 18,3 & 20,3 & 13,7 & 16,9 & 17,8 \\
\hline $25-54$ & 67,5 & 67,5 & 70,1 & 67,9 & 61,1 \\
\hline $55-64$ & 14,2 & 12,2 & 16,2 & 15,2 & 21,1 \\
\hline Összesen & 100,0 & 100,0 & 100,0 & 100,0 & 100,0 \\
\hline \multicolumn{6}{|l|}{ Iskolai végzettség } \\
\hline $\begin{array}{l}\text { érettségizettek aránya a } \\
\text { 18-64 évesek körében }\end{array}$ & 62,7 & 69,5 & 67,9 & 75,2 & 53,5 \\
\hline \multicolumn{6}{|l|}{$\begin{array}{l}\text { felsőfokú végzettségüek } \\
\text { aránya a 25-64 évesek } \\
\text { körében }\end{array}$} \\
\hline \multicolumn{6}{|l|}{ Anyanyelv } \\
\hline magyar & 25,2 & 11,7 & 56,5 & 38,5 & 83,9 \\
\hline más & 27,7 & 34,2 & 15,5 & 25,3 & 0,9 \\
\hline nincs válasz & 47,1 & 54,1 & 28,0 & 36,2 & 15,2 \\
\hline Összesen & 100,0 & 100,0 & 100,0 & 100,0 & 100,0 \\
\hline \multicolumn{6}{|l|}{ A lakóhely településtípusa } \\
\hline Budapest & 40,6 & 50,3 & 34,8 & 42,0 & 17,5 \\
\hline többi város & 37,6 & 37,8 & 43,1 & 43,1 & 52,4 \\
\hline község & 21,8 & 11,9 & 22,1 & 14,9 & 30,1 \\
\hline Összesen & 100,0 & 100,0 & 100,0 & 100,0 & 100,0 \\
\hline N 15-64 & 112274 & 46595 & 266507 & 88674 & 6812849 \\
\hline N 18-64 & 108923 & 45029 & 260582 & 86273 & 6465545 \\
\hline N25-64 & 91654 & 37137 & 229946 & 73725 & 5601080 \\
\hline
\end{tabular}

Forrás: KSH, 2011. évi népszámlálás. Saját számítás.

Megjegyzés: A teljes népesség a népszámlálás idején Magyarországon élő lakónépességet jelenti, amely magába foglalja a legalább egy évig itt tartózkodó külföldi állampolgárokat, illetve külföldön születetteket is. 
A magyarországi bevándorlás jól ismert sajátossága, hogy a bevándorlók jelentős - noha az utóbbi években csökkenő - hányada magyar anyanyelvű. Körükben a magyar állampolgárság megszerzése gyakoribb, így 2011-ben a külföldi állampolgároknak mindössze egynegyede vallotta magát magyar anyanyelvünek, míg a külföldi születésű népesség 57\%-a. Ugyanakkor mindkét csoportban nagyon magas volt a válaszhiány (47\%, illetve 28\%). A magyar anyanyelvűek legkisebb aránya (12\%) és egyben a legnagyobb válaszhiány (54\%) a harmadik országbeli állampolgároknál figyelhető meg, akiknek több mint a fele Európán kívüli országból származott. A származási csoportok között jelentős eltérések vannak: a négy szomszédos ország valamelyikében született 15-64 évesek 63-78\%-a vallotta magát magyar anyanyelvűnek (a kérdésre válaszolók 84-96\%-a), az ázsiai országokból származók esetében azonban ez az arány többnyire 5\% alatti.

A bevándorlók integrációs lehetőségeit a letelepedési helyük gazdasági, társadalmi kontextusa is meghatározza. A külföldi népesség területi elhelyezkedése sajátos képet mutat: főként a közép-magyarországi régióban, és ezen belül a fővárosban vannak jelentősen felülreprezentálva, ahol jobbak az elhelyezkedési esélyek. Míg a teljes aktív korú népesség 17,5\%-a élt Budapesten 2011-ben, a külföldi születésủ népességnél ez az arány 35\%, a külföldi állampolgároknál pedig 41\% volt. Az észak-magyarországi régióban, valamint a kisebb városokban és a községekben viszont a külföldiek összességében alulreprezentáltak. Főként a harmadik országbeli állampolgárok élnek nagy arányban a fővárosban (50\%) és kevésbé a községekben (12\%). A születési ország e tekintetben is meghatározó: míg a 15-64 éves vietnámi születésű népesség 89\%-a, a kínaiak 78\%-a és a szíriaiak kétharmada a fővárosban élt, néhány nyugat-európai országból érkezett csoport - a hollandiai, a svájci, az ausztriai születésủek - jóval átlag feletti (44-52\% közötti) arányban választotta a községeket. Ez a migrációs motivációkkal is összefügg, hiszen a községekben élő külföldiek demográfiai és munkaerő-piaci jellemzői teljesen mások, mint a nagyobb városokban letelepedőké (Kincses 2015).

A fogadó országban töltött idő figyelembevétele szintén fontos az integrációs mutatók értékeléséhez, az erre vonatkozó információ azonban hiányos: a 15-64 éves külföldi állampolgárok 59\%-a esetében ismert az érkezés éve (további 1,9\%-uk Magyarországon született), a külföldi születésủeknek pedig a 76\%-ánál. ${ }^{20} \mathrm{Az}$ érkezési idő szerinti megoszlásuk arra utal, hogy a 2011-ben Magyarországon élő aktív korú külföldi születésủ népesség jelentős hányada még a rendszerváltozás előtt, illetve a kilencvenes évek első felében érkezett, míg az ugyanebbe a korcsoportba tartozó

\footnotetext{
${ }^{20}$ Továbbá a külföldi állampolgárok 1,6\%-a, a külföldi születésüek 5\%-a egyéves kora előtt érkezett, az ő esetükben a
} Magyarországra költözés idejét nem rögzítette a népszámlálás, ezt születési évük alapján becsültük. 
külföldi állampolgárok zöme az ezredforduló - és leginkább 2004 - után (1. ábra). Az előbbiek átlagosan mintegy 15 éve, az utóbbiak közel 9 éve éltek Magyarországon. A külföldön születettek egyes csoportjainál azonban ez az idő 3 és 27 év között mozgott.

1. ábra: A 15-64 éves külföldi állampolgárságú és külföldi születésü népesség megoszlása a Magyarországra érkezés ideje szerint

Distribution of foreign citizens and foreign-born population aged 15-64 by year of arrival in Hungary

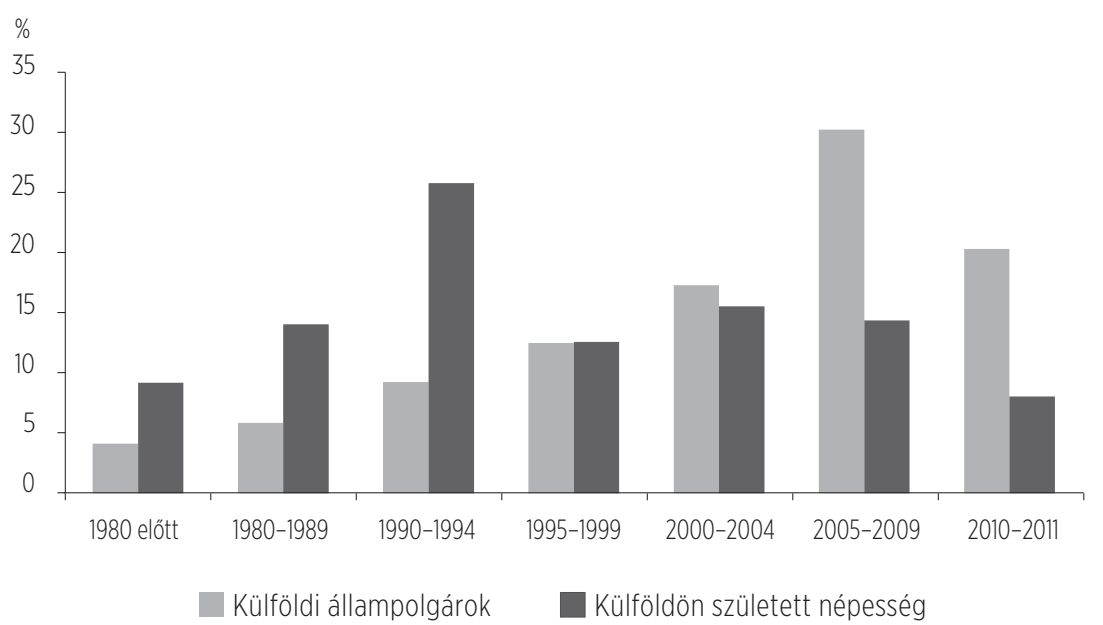

Forrás: KSH, 2011. évi népszámlálás. Saját számítás.

Megjegyzés: A megoszlás mindkét csoport esetében azokra vonatkozik, akik külföldön születtek és ismert a Magyarországra költözésük ideje.

\section{ÁLTALÁNOS HELYZETKÉP A ZARAGOZAI INDIKÁTOROK ALAPJÁN}

Ha áttekintjük a Magyarországon élő külföldi állampolgárságú, illetve külföldi születésű népesség különböző integrációs mutatóit, alapvetően egy pozitív kép rajzolódik ki (4. táblázat). A munkavállalási korú, 15-64 éves korcsoportban a munkaerő-piaci mutatóik összességében jobbak, mint a hazai népességé: a foglalkoztatottak aránya és az aktivitási arány is magasabb - különösen a külföldi születésủek körében -, a munkanélküliségi ráta pedig számottevően kisebb. ${ }^{21}$

\footnotetext{
${ }^{21}$ A 20-64 éves korcsoportban - amelynél az Európa 2020 stratégia a 75\%-os foglalkoztatottság elérését tủzte ki célul - a külföldi születésüek 72\%-a, a külföldi állampolgárok 70,2\%-a, a teljes népesség 66,4\%-a volt foglalkoztatott.
} 
4. táblázat: A külföldi állampolgárságú és a külföldi születésü népesség integrációs mutatói (a 15-64 éves korcsoportra, ha másképp nem szerepel), \%

Integration indicators of foreign citizens and foreign-born population (aged 15-64 unless otherwise indicated), \%

\begin{tabular}{|c|c|c|c|c|c|}
\hline $\begin{array}{l}\text { Integrációs mutatók az egyes } \\
\text { területeken }\end{array}$ & $\begin{array}{l}\text { Külföldi } \\
\text { állam- } \\
\text { polgárok }\end{array}$ & $\begin{array}{l}\text { Harmadik } \\
\text { országbeli } \\
\text { állam- } \\
\text { polgárok }\end{array}$ & $\begin{array}{l}\text { Külföldön } \\
\text { született } \\
\text { népesség }\end{array}$ & $\begin{array}{l}\text { Harmadik } \\
\text { országban } \\
\text { született } \\
\text { népesség }\end{array}$ & $\begin{array}{c}\text { Teljes } \\
\text { népesség }\end{array}$ \\
\hline \multicolumn{6}{|l|}{ Munkaerőpiac } \\
\hline Foglalkoztatási ráta & 62,4 & 61,7 & 65,5 & 63,0 & 57,0 \\
\hline Munkanélküliségi ráta & 6,5 & 5,5 & 8,7 & 8,1 & 12,7 \\
\hline Aktivitási arány & 66,7 & 65,2 & 71,7 & 68,6 & 65,3 \\
\hline $\begin{array}{l}\text { Túlképzettek aránya (a } \\
\text { felsőfokú végzettségü } \\
\text { foglalkoztatottak körében) }\end{array}$ & 18,8 & 24,7 & 15,3 & 19,6 & 12,8 \\
\hline $\begin{array}{l}\text { Önfoglalkoztatók, vállalkozók } \\
\text { aránya }\end{array}$ & 10,5 & 13,6 & 9,2 & 12,1 & 7,4 \\
\hline \multicolumn{6}{|l|}{ Oktatás } \\
\hline $\begin{array}{l}\text { Felsőfokú végzettségűek } \\
\text { arányaa }\end{array}$ & 26,9 & 31,9 & 29,6 & 38,3 & 19,5 \\
\hline $\begin{array}{l}\text { Legfeljebb alapfokú } \\
\text { végzettségűek arányaa }\end{array}$ & 18,9 & 16,9 & 12,7 & 12,3 & 19,9 \\
\hline $\begin{array}{l}\text { Felsőfokú végzettségűek } \\
\text { aránya a 30-34 évesek } \\
\text { körében }\end{array}$ & 33,0 & 37,0 & 36,0 & 42,4 & 27,3 \\
\hline $\begin{array}{l}\text { Korai iskolaelhagyók aránya } \\
\text { (18-24 évesek) }\end{array}$ & 12,8 & 9,9 & 10,5 & 7,7 & 12,6 \\
\hline \multicolumn{6}{|l|}{ Egészségi állapot } \\
\hline $\begin{array}{l}\text { Tartós betegséggel és/ } \\
\text { vagy fogyatékossággal } \\
\text { rendelkezők aránya }\end{array}$ & 5,9 & 4,3 & 9,3 & 7,9 & 15,0 \\
\hline \multicolumn{6}{|l|}{ Lakhatás } \\
\hline Ingatlantulajdonosok aránya & 60,1 & 59,5 & 72,0 & 69,6 & 86,2 \\
\hline $\begin{array}{l}\text { Túlzsúfolt lakásban élők } \\
\text { aránya }\end{array}$ & 25,8 & 27,0 & 22,3 & 22,3 & 22,6 \\
\hline \multicolumn{6}{|l|}{ Honosítás } \\
\hline $\begin{array}{l}\text { Magyar állampolgársággal (is) } \\
\text { rendelkezők aránya }\end{array}$ & - & - & 58,8 & 48,1 & 98,4 \\
\hline
\end{tabular}

Forrás: KSH, 2011. évi népszámlálás. Saját számítás.

a Az iskolai végzettség szerinti megoszlás a 15-64 éves és már nem tanuló népességre vonatkozik. 
A harmadik országból származó külföldi állampolgárok körében a legalacsonyabb az aktivitási arány (azonos a teljes népességével), viszont a munkanélküliségi ráta is itt a legkisebb, a túlképzettek aránya (a felsőfokú végzettséggel rendelkező foglalkoztatottak körében) viszont a legnagyobb (25\%), mintegy kétszerese a teljes népességben mért értéknek (13\%). Mindez arra utal, hogy a bevándorlók azon csoportjában, amelyik összességében rövidebb ideje tartózkodik itt, (még) nem szerzett magyar állampolgárságot és EU-n kívüli országból származik, az átlag feletti foglalkoztatottság mellett jelentős mértékű a tudástőke elfecsérlése (brain waste). Ez adódhat a külföldön szerzett végzettség elismertetésének nehézségéből, a szakértelem/készségek átkonvertálásának nehézségéből, a nyelvi korlátokból, vagy pusztán abból, hogy e csoport egy része még az integrációs folyamat elején tart. Ugyancsak körükben a legnagyobb az önfoglalkoztatók, vállalkozók aránya is (mintegy kétszerese a teljes népességbeli aránynak), ami szintén jelezhet egyfajta kényszerpályát (lásd erről a későbbiekben).

A 15-64 éves külföldi születésü népesség - amelynek közel 60\%-a rendelkezik magyar állampolgársággal - munkaerő-piaci mutatói összességében jobbak, körükben a túlképzettek aránya is csak kevéssel haladja meg a teljes népességre jellemző értéket, ám a harmadik országból származók helyzete e csoporton belül is valamivel rosszabb.

Az oktatás területén vizsgált mutatók elsősorban a bevándorlók pozitív szelekcióját tükrözik (4. táblázat). A felsőfokú végzettségüek aránya a külföldiek mindkét csoportjában nagyobb, mint a teljes népességben, és különösen magas az EU-n kivüli országban születettek körében. Ugyanakkor szemben az általános európai trenddel, miszerint a bevándorlók a képzettségi skála mindkét végén felülreprezentáltak (OECD/European Union 2014), a magyarországi bevándorlók körében az alacsony (legfeljebb 8 osztályos) végzettséggel rendelkezők aránya csak a külföldi állampolgárok esetében közelíti meg a teljes népességét, a külföldi születésű népesség esetében jóval alatta marad. Noha a magasabb iskolázottság részben a fiatalabb korösszetételből adódik, jól látható, hogy a 30-34 éves - az Európa 2020 stratégiában kiemelt - korcsoportban is nagyobb a felsőfokú végzettségűek aránya a bevándorlók mindkét csoportjában, de különösen a harmadik országból származóknál. A korai iskolaelhagyók - azaz a 18-24 évesek közt a már nem tanuló és legfeljebb 8 osztályos végzettséggel rendelkezők - aránya ugyanakkor éppen a harmadik országban születetteknél a legalacsonyabb, míg a külföldi állampolgárok közt azonos a teljes népességben mért aránnyal. 
Az egészségi állapot szubjektív értékelése helyett csak egy közelítő mutató - a tartós betegséggel és/vagy fogyatékossággal rendelkezők aránya - áll rendelkezésünkre. Ez alapján a 15 és 64 év közötti külföldi születésű népesség, és még inkább a külföldi állampolgárok helyzete lényegesen jobb, mint a teljes népességé. Az életkor és iskolai végzettség szerinti összetételük mellett ez feltehetően a migráció szelekciós hatásának is köszönhető.

Az ingatlantulajdonosok aránya ${ }^{22}$ viszont a bevándorlók mindkét csoportjában számottevően kisebb, mint a teljes népességben. A külföldi állampolgárok - akik zömében a népszámlálást megelőző tíz évben érkeztek - a teljes külföldi születésű népességhez képest is kisebb arányban éltek saját ingatlanban, ugyanakkor a túlzsúfolt lakásban élők aránya ${ }^{23}$ (ami a zaragozai indikátorok közt nem, csak az újabban javasoltak közt szerepel) kissé nagyobb volt körükben, mind a külföldi születésü, mind a teljes népességhez képest.

A magyar állampolgársággal (is) rendelkezők aránya a 15-64 éves külföldön született népességben viszonylag magas (59\%). Míg azonban a négy szomszédos országból származók közel háromnegyede (72\%), az EU-n kívüli országokban születettek kevesebb, mint fele (48\%) volt honosított, és különösen alacsony ez az arány az ázsiai származásúaknál (18,5\%). Noha fontos lenne a mutatót a honosításra jogosult külföldi születésüekre számolni, az ehhez szükséges adatok a népszámlálásban nem szerepelnek, vagy hiányosak (pl. az érkezés ideje).

Az áttekintett integrációs mutatók alapján csak a túlképzettséget és a lakáskörülményeket illetően voltak rosszabb helyzetben a bevándorlók leginkább az integráció szempontjából kiemelt figyelmet kapó harmadik országbeli állampolgárok - a hazai népességnél. Kérdés azonban, hogy ez mennyire a sajátos összetételüknek, szelekciójuknak köszönhető, illetve ennek hatását kiszürve milyen szerepe van a külföldi születési helynek vagy a külföldi állampolgárságnak. A migráns népesség heterogenitása arra enged következtetni, hogy a pozitív összkép jelentős származási országok szerinti különbségeket takar. Ezt a társadalmi-demográfiai és egyéb jellemzők eltérései mellett bizonyos országspecifikus, kulturális sajátosságok is meghatározhatják. A továbbiakban a munkaerő-piaci mutatók vonatkozásában részletesen is megvizsgáljuk, hogy melyek azok a „,törésvonalak”, amelyek mentén az eltérések kirajzolódnak, és milyen tényezők határozzák meg a sikeres integrációt.

22 A népszámlálás alapján azokat soroltuk ide, akik az adott lakásban tulajdonosként, annak rokonaként vagy haszonélvezőként laktak.

${ }^{23}$ A túlzsúfolt lakásban élők meghatározásához a KSH az Eurostat-definíciónak megfelelően vette figyelembe a háztartás összetételét és a szobák számát (lásd erről: KSH 2016). 


\section{A BEVÁNDORLÓK MUNKAERÖ-PIACI HELYZETÉNEK SOKFÉLESÉGE}

Magyarországon a munkavállalási korú bevándorlóknak a hazai népességhez képest összességében jobb munkaerő-piaci helyzetét korábbi elemzések és a legfrissebb Eurostat-adatok is alátámasztják (Hárs 2010, Gödri 2011, 2016, Eurostat 2016). Ez utóbbi (az EU-LFS-re épülő) adatok alapján az EU28-ban összességében a külföldi állampolgárokra kisebb foglalkoztatási arány és magasabb munkanélküliségi ráta jellemző, mint a honos népességre. ${ }^{24}$ Ugyanakkor a más EU-tagállamból származók ezen mutatói valamelyest jobbak, a nem EU-állampolgároké - és e csoporton belül főként a nőké - viszont sokkal rosszabbak, mint a fogadó népességé (Eurostat 2016). Ezzel szemben Magyarországon - az általános európai trenddel ellentétben a külföldi állampolgárok foglalkoztatási aránya az LFS-adatok alapján is kissé magasabb, mint a hazai népességé, és ez a nem EU-állampolgárokra is igaz. A munkanélküliségi ráta - amely csak a népszámlálás alapján hasonlítható össze ${ }^{25}$ - a harmadik országbeli állampolgárok körében a legalacsonyabb (5,5\%), ami abból adódik, hogy e csoportban magas az eltartottak, azaz a munkaerőpiacra be sem lépők aránya (a 15-64 éves korcsoportban 23\%, szemben a teljes népesség hasonló korcsoportjára jellemző 15\%-kal).

A bevándorlók munkaerő-piaci helyzete a különböző társadalmi-demográfiai csoportokban eltérő jellegzetességeket mutat. Mind a külföldi születésű, mind a külföldi állampolgárságú népességben a férfiak aktivitási és foglalkoztatási aránya nagyobb, munkanélküliségi rátája kisebb, mint a nőké, és a nemek közötti rés nagyobb, mint a teljes népességben (M2. táblázat). A legnagyobb foglalkoztatási arány a 30 és 54 év közöttieknél figyelhető meg, de valamennyi 30 év feletti korcsoportban, valamint a 15-19 éveseknél is meghaladja a teljes népességét. A 20 és 29 év közötti külföldi állampolgárok foglalkoztatottsága azonban elmarad a teljes népességétől, ami abból adódik, hogy - a tanulási célú migráció következtében - magas körükben a tanulók aránya. (Ha a nem tanulók esetében hasonlítjuk össze a foglalkoztatási rátákat, valamennyi korcsoportban nagyobb a bevándorlóké, mint a teljes népességé). A nemek közötti eltérés azonban itt is megfigyelhető: míg a külföldi születésü, illetve a külföldi állampolgárságú férfiak foglalkoztatási rátája valamennyi 30 év feletti korcsoportban számottevően magasabb, mint a fogadó népességé, a nőknél

\footnotetext{
${ }^{24}$ A bevándorlók és a honos népesség foglalkoztatottsága, illetve munkanélkülisége közötti rés a 2008-as gazdasági válság után kissé szélesedett, különösen a válság által jobban sújtott országokban (OECD/European Union 2015).

${ }^{25}$ Magyarország esetében a külföldi állampolgárok munkanélküliségi rátáját a rájuk vonatkozó LFS-adatok alacsony megbízhatóságára hivatkozva nem közli az Eurostat.
} 
a különbségek jóval szerényebbek és inkább csak a 40 év feletti külföldi születésűek esetében mutatkoznak (Gödri 2016). A külföldi állampolgárságú nőknél az aktivitási arány is kisebb a 20 és 54 év közötti korcsoportokban, mint a fogadó népességbeli hasonló korú nőknél.

A munkanélküliség leginkább a 20 év alatti külföldi állampolgárokat, illetve a 25 év alatti külföldi születésüeket érinti, de ezekben a korcsoportokban is jelentősen elmarad a teljes népességéhez képest (M2. táblázat). A fiatalkori munkanélküliségi ráta (a 15-24 éves aktív népességben) 8\% a külföldi állampolgárságú férfiak és 11\% a külföldi állampolgárságú nők esetében, míg a külföldi születésűeknél 13\%, illetve $15 \%$, a teljes népességben pedig 22\%, illetve $24 \%$.

Az iskolai végzettség szintén fontos differenciáló tényező: növekedésével a bevándorlók esetében is nő a foglalkoztatási ráta, és csökken a munkanélküliségi ráta, azonban a szakmunkás végzettségüek és az érettségizettek mutatói között nincs lényeges különbség (M3. táblázat). A teljes népességgel összehasonlítva jelentősebb eltérések csak az alacsonyabb végzettségi szinteken vannak és egyértelmüen a bevándorlók javára: a szakmunkás végzettségü külföldiek foglalkoztatási rátája kismértékben, az alacsonyabb iskolai végzettségűeké pedig jelentősen meghaladja a teljes népességét, míg a munkanélküliségi rátájuk kisebb. Noha az európai országok többségében a felsőfokú végzettségü bevándorlók foglalkoztatottsága jelentősen elmarad a hasonló végzettségű fogadó népességhez képest (OECD/European Union 2015), Magyarországon ez nem jellemző.

A különböző származási csoportok foglalkoztatási helyzete azonban nagyon eltérő. Erre már az előző, 2001-es népszámlálás eredményei (Gödri 2011), valamint a migránsok különböző csoportjai körében végzett korábbi surveyek is rávilágítottak (ez utóbbiak áttekintését lásd: Kováts 2013). E vizsgálatokból jól látható, hogy a bevándorlók munkaerő-piaci helyzetét „markáns különbségek”, „,sokféleség” és „,nagyfokú egyenlőtlenség” jellemzi (Örkény - Székelyi 2010, Juhász et al. 2011, idézi: Kováts 2013).

A származási ország szerinti különbségek a külföldi születésű népesség munkaerő-piaci mutatóiban a 2011-es népszámlálásból is kirajzolódnak. A 15-64 éves külföldi születésűek foglalkoztatási aránya 40,5\% (Görögország) és 79,5\% (Kína) között változott, és hasonlóan széles határok közt mozgott az aktivitási arány is (41\% és 81\% között). ${ }^{26}$ A gazdaságilag aktívabb 25-64 éves korcsoportban mindkét mutató értéke magasabb volt, ám az országok közötti ingadozásuk szintén jelentős. A nemek szerinti mutatók alapján valamennyi

${ }^{26} \mathrm{Az}$ összehasonlitáshoz 34 születési országot vettünk figyelembe (az említett 32 - legalább 1000 fös - csoport mellett két 900 fő feletti csoportot is), ezek összességében a teljes külföldi születésủ népesség 95\%-át lefedik. 
származási csoportnál kivétel nélkül a férfiak magasabb foglalkoztatottsága figyelhető meg (2a. ábra). Míg azonban egyes csoportoknál (kínaiak, vietnámiak) a nőkre is magas foglalkoztatottság volt jellemző, más csoportok esetében (például szíriaiak) a férfiak magas foglalkoztatási rátája a nők különösen alacsony foglalkoztatottságával párosul, vagy pedig mind a nők, mind a férfiak foglalkoztatási rátája elmarad a hazai népességhez képest (svájciak, hollandok).

2. ábra: A 25-64 éves külföldi születésü népesség munkaerő-piaci mutatói születési országok és nemek szerint

Labour market indicators of the foreign-born population aged 25-64 by country of birth and gender

a. Foglalkoztatási arány

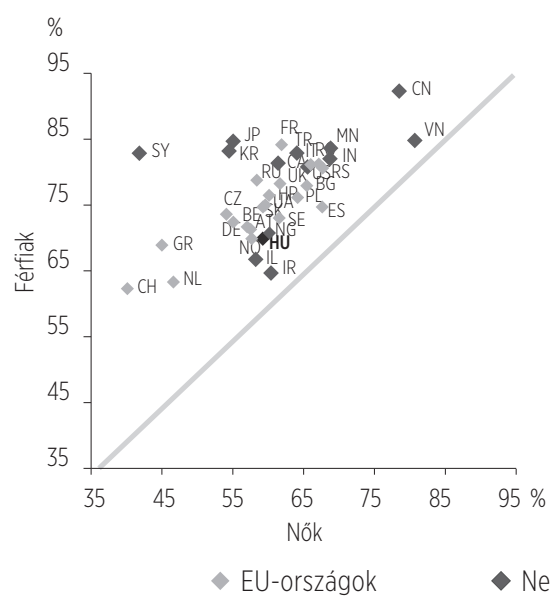

b. Munkanélküliségi ráta

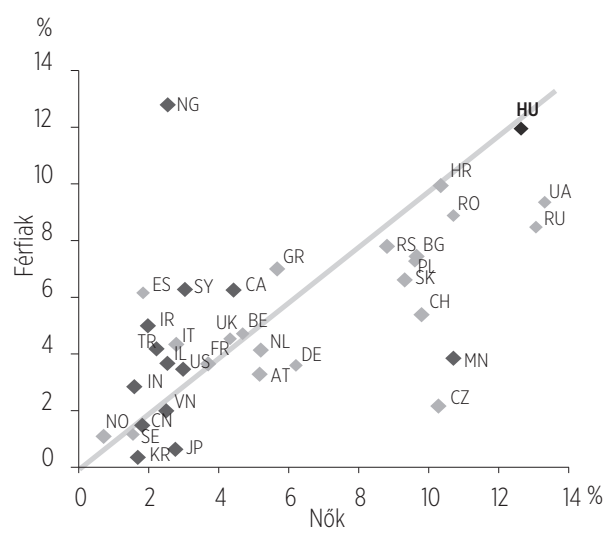

Forrás: KSH, 2011. évi népszámlálás. Saját számítás.

A munkanélküliségi ráták még nagyobb szóródást mutatnak (2b. ábra), azonban a legtöbb származási csoport esetében (az orosz és az ukrán nők, valamint a nigériai férfiak kivételével) mindkét nem munkanélküliségi rátája kisebb - az esetek zömében jelentősen kisebb -, mint a teljes népességben mért érték. A nők alacsony foglalkoztatottsága tehát nem minden esetben jár együtt magas munkanélküliségi rátával, ami arra utal, hogy sokan közülük be sem lépnek a munkaerőpiacra (egy részük vélhetően rejtett munkanélküli). Ezt az eltartottak magas aránya is tükrözi a nők különböző csoportjaiban (például szíriai, norvég, dél-koreai, japán, iráni, izraeli és török nők), ami feltehetően részben a tradicionális női szerepeket elfogadó értékrenddel, részben egyéb - a migráció körülményeivel, motivációival összefüggő - okokkal magyarázható. 
A származási ország szerinti különbségek arra is rávilágítanak, hogy bár összességében az EU-tagállamokból származó bevándorlók munkaerőpiaci mutatói jobbak, mint az EU-n kívüli úgynevezett harmadik országokból származóké, a két országcsoporton belül is jelentős eltérések vannak az egyes országok között.

\section{Túlképzettség}

A foglalkoztatottság mellett a tudástőke hasznosítása, a képzettségnek megfelelő munka szintén fontos mutatója a munkaerő-piaci integráció sikerességének. Noha az iskolai végzettség nagymértékben meghatározza a munkaerő-piaci esélyeket, a bevándorlók esetében nagyobb a kockázata a különböző képzettségek leértékelődésének, és a külföldön szerzett végzettség megtérülése többnyire rosszabb. Ebből adódik, hogy a munkaerő-piaci egyenlőtlenségek a bevándorlók és a fogadó népesség között általában nőnek az iskolai végzettséggel (OECD/ European Union 2014). Magyarországon (mint az M3. táblázatból is láthattuk) a felsőfokú végzettségü bevándorlók foglalkoztatási rátája 2011-ben összességében alig maradt el a teljes népességéhez képest: a külföldi állampolgároké 3, a külföldi születésűeké mindössze 1 százalékponttal volt kisebb. A túlképzettség - azaz a felsőfokú végzettségü foglalkoztatottak körében az alacsony vagy közepes képzettséget igénylő munkát végzők aránya - azonban nagyobb volt a külföldiek körében: míg a 25-64 éves teljes népességben 12,4\%, a külföldi születésüeknél 14,9\%, a külföldi állampolgároknál pedig 18,4\%. ${ }^{27}$ Leginkább a külföldi állampolgárságú nők esetében fordult elő a túlképzettség (közülük a felsőfokú végzettségü foglalkoztatottak egyötöde dolgozott alacsonyabb képzettséget igénylő munkakörben), illetve mindkét nemnél a harmadik országból származók esetében (5. táblázat). A 2014-es munkaerő-felmérés (MEF) a magyar állampolgárok körében a túlképzettség hasonló arányát mérte mindkét nem esetében, a harmadik országbeli állampolgárok - és különösen a nők - esetében viszont jóval kisebb értékeket (lásd: KSH 2015). A 2007 és 2012 közötti időszakra összevont MEF adatok viszont a nem EU-állampolgárok körében szintén nagyon magas, 28,7\%-os túlképzettséget mutatnak (Hárs 2013). ${ }^{28}$ Az EU28-ban élő harmadik országbeli állampolgárok körében 2012-2013-ban ennél is nagyobb arányú volt a túlképzettség (44\%), és a nőké összességében mintegy 11 százalékponttal haladta meg a férfiakét (OECD/European Union 2015).

\footnotetext{
${ }^{27}$ Ezek az értékek közel azonosak a 15-64 éves korcsoportra számított értékekkel (lásd: 4. táblázat).

${ }^{28}$ A nemek szerinti bontást azonban az alacsony elemszám miatt nem közlik.
} 
A túlképzettség nemek szerinti különbségeit érdemes a foglalkoztatási arányokkal együtt vizsgálni. Ez alapján megállapítható, hogy noha a felsőfokú végzettségű nők túlképzettsége Magyarországon csak a külföldi állampolgárok esetében és csak kismértékben haladja meg a férfiakét, a foglalkoztatási rátájuk mind a külföldi állampolgárok, mind a külföldi születésủek esetében számottevően alacsonyabb, mint a férfiaké, és elmarad a fogadó népességbeli nőkéhez képest is (5. táblázat).

5. táblázat: A foglalkoztatási arány és a túlképzettség a 25-64 éves felsőfokú végzettségüek körében nemek szerint (\%)

Employment rate and overqualification among foreign citizens and foreign-born population aged 25-64 with tertiary education by gender (\%)

\begin{tabular}{|c|c|c|c|c|c|}
\hline Demográfiai csoport & $\begin{array}{l}\text { Külföldi } \\
\text { állam- } \\
\text { polgárok }\end{array}$ & $\begin{array}{c}\text { Harmadik } \\
\text { országbeli } \\
\text { állam- } \\
\text { polgárok }\end{array}$ & $\begin{array}{l}\text { Külföldön } \\
\text { született } \\
\text { népesség }\end{array}$ & $\begin{array}{c}\text { Harmadik } \\
\text { országban } \\
\text { született } \\
\text { népesség }\end{array}$ & $\begin{array}{c}\text { Teljes } \\
\text { népesség }\end{array}$ \\
\hline & \multicolumn{5}{|c|}{ Foglalkoztatási arány } \\
\hline Férfi & 84,5 & 82,4 & 85,7 & 83,9 & 84,5 \\
\hline Nő & 68,7 & 65,2 & 71,8 & 68,1 & 76,1 \\
\hline Együtt & 76,6 & 73,9 & 78,2 & 75,6 & 79,6 \\
\hline \multirow[t]{2}{*}{ N } & 26759 & 12627 & 72105 & 29456 & 1176880 \\
\hline & \multicolumn{5}{|c|}{ Túlképzettség } \\
\hline Férfi & 17,4 & 24,0 & 14,4 & 19,1 & 13,0 \\
\hline Nő & 19,7 & 24,8 & 15,4 & 19,5 & 11,9 \\
\hline Együtt & 18,4 & 24,4 & 14,9 & 19,3 & 12,4 \\
\hline N & 20507 & 9334 & 56386 & 22268 & 937343 \\
\hline
\end{tabular}

Forrás: KSH, 2011. évi népszámlálás. Saját számitás.

A túlképzettség származási országok szerint is nagyon eltérő: kiugróan magas a vietnámi és a kínai születésủeknél (61\%, illetve 46\%), de a mongóliai, szíriai, nigériai és török származásúak esetében is legalább 25\%-os. Ugyanakkor, míg a külföldi születésű és felsőfokú végzettségü népességben a férfiak magasabb foglalkoztatási rátája minden származási csoport esetében megfigyelhető (bár a nemek közötti foglalkoztatottsági rés nagyon különböző mértékű), a túlképzettséget illetően változó a nemek szerinti különbség (3. ábra). A származási csoportok többségében a nők túlképzettségi aránya nagyobb, mint a férfiaké (különösen magas a vietnámi származású nőknél), de a csoportok egyharmadánál közel azonos a két nemnél, és néhány esetben a férfiak túlképzettsége a nagyobb. 
3. ábra: A foglalkoztatási arány (felső tengely) és a túlképzettség (alsó tengely) a 25-64 éves felsőfokú végzettségü külföldön született népességben születési országok és nemek szerint Employment rate and overqualification among foreign-born population aged 25-64 with tertiary education by country of birth and gender

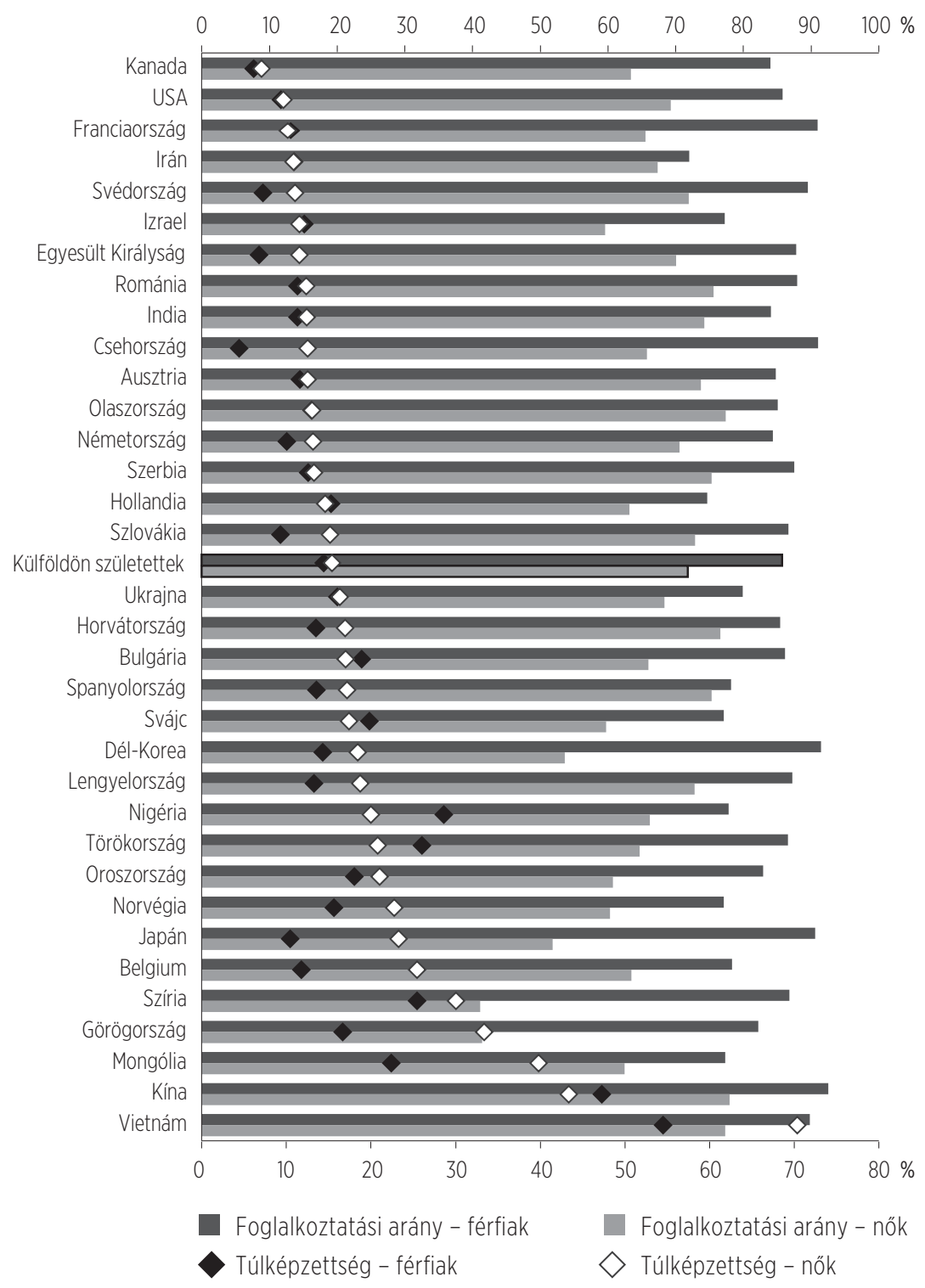

Forrás: KSH, 2011. évi népszámlálás. Saját számítás.

Megjegyzés: Az adott korcsoportban a felsőfokú végzettségű foglalkoztatott nők száma öt ország (Görögország, Szíria, Norvégia, Nigéria és Svájc) esetében 50 fő alatti. 
A túlképzettség nemcsak nemek és kibocsátó országok szerint, hanem életkor (az ebből adódó korábbi tapasztalat), a felsőfokú végzettség jellege, a magyar nyelv ismerete, az érkezés óta eltelt idő, valamint az országon belüli letelepedési hely szerint is változó mértékü lehet. E tényezők többségét a többváltozós elemzés során majd figyelembe vesszük.

\section{Önfoglalkoztatók, vállalkozók}

A bevándorlók munkaerő-piaci helyzetéről a foglalkoztatottak aránya mellett a foglalkoztatás formája is sokat elárul. Az önfoglalkoztatók, vállalkozók aránya jelzi, hogy milyen mértékben és a migránsok mely csoportjaiban elterjedt a primer munkaerő-piacra való belépés helyett a saját (etnikai) vállalkozás. A migráns vállalkozások létrejöttében a különböző okokból - például nyelvtudás hiánya, a végzettség elismertetésének nehézsége, vagy diszkrimináció miatti elhelyezkedési nehézségek - fakadó kényszer mellett kulturális és kapcsolathálózati tényezők is szerepet játszhatnak. Bizonyos származási csoportoknál az etnikai gazdaságok müködtetése elterjedt gazdasági stratégia, amely az etnikai közösségen belüli erőforrásokra, bizalomra és gyakran transznacionális kapcsolatrendszerekre épül (Kováts 2013).

A népszámlálás alapján 2011-ben a 15-64 éves foglalkoztatottak körében az egyéni vállalkozók, önállók aránya a külföldi születésủek közt alig volt nagyobb (9,2\%), mint a teljes népességben (7,4\%), viszont a külföldi állampolgárok körében, és különösen a harmadik országból származók esetében már magasabb volt az arányuk (10,5\%, illetve 13,5\%). Az egyéni vállalkozók mellett a társas vállalkozások tagjaként dolgozók aránya is nagyobb volt ez utóbbi csoportokban: míg a teljes külföldi születésű népességben másfélszerese (6,3\%), a harmadik országbeli állampolgároknál mintegy kétszerese (9,4\%) a teljes népességbeli aránynak (4,3\%). A 2014-es munkaerő-felmérés a teljes népességben mindkét foglalkoztatási forma hasonló arányát mutatta, a harmadik országbeli állampolgárok körében azonban az egyéni vállalkozók kisebb (11\%), míg a társas vállalkozás tagjaként dolgozók jóval nagyobb (18\%) arányban jelentek meg (KSH 2015).29 2012-2013-ban az EU28-ban élő harmadik országbeli állampolgárok körében 11\%-os volt az önfoglalkoztatók aránya, azonos a honos népességével (OECD/European Union 2015).

\footnotetext{
${ }^{29}$ Mivel mind a túlképzettség, mind a vállalkozók aránya a teljes népességben hasonló volt a népszámlálás és a munkaerőfelmérés szerint, a harmadik országbeli állampolgároknál tapasztalható jelentős eltérések mögött a munkaerő-felmérésnek e csoportra vonatkozó reprezentativitási hibája sejthető.
} 
4. ábra: Az önfoglalkoztatók és a társas vállalkozások tagjaként dolgozók aránya a külföldi születésü 15-64 éves foglalkoztatottak körében születési országonként

Self-employed and those working as members of an companyenterprise among foreign-born employed aged 15-64 by country of birth

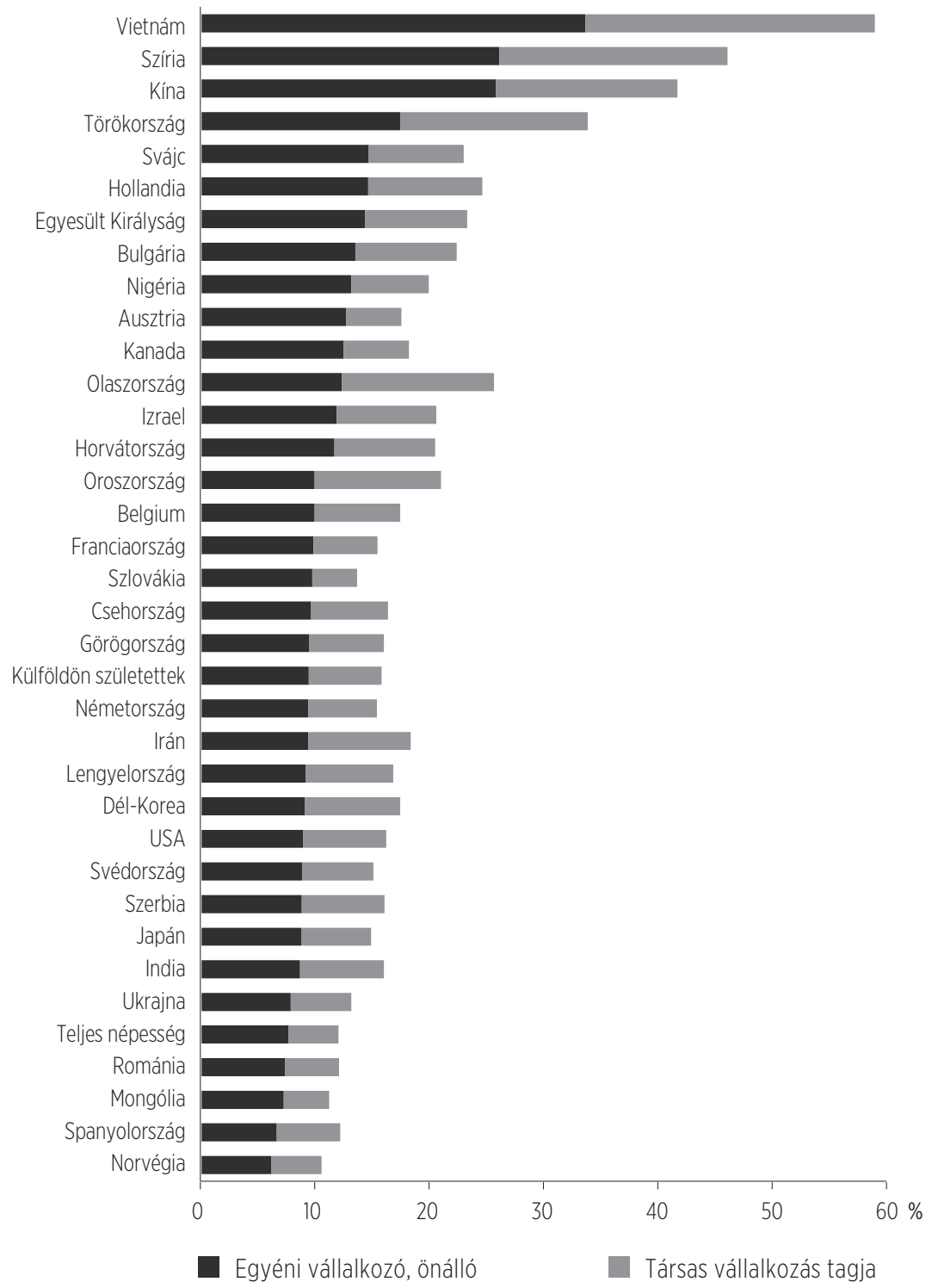

Forrás: KSH, 2011. évi népszámlálás. Saját számítás. 
Az önfoglalkoztatás a külföldi születésú népesség bizonyos csoportjaiban kiugróan magas arányban fordult elő: a 15-64 éves foglalkoztatott vietnámiak 33\%-a, a kínaiak és a szíriaiak 26\%-a, a törökök 17\%-a volt egyéni vállalkozó, önálló (4. ábra). Ezekben a csoportokban ugyanakkor a társas vállalkozások tagjaként dolgozók aránya is az átlagosnál jóval magasabb volt, így összességében a foglalkoztatottak 33-58\%-a feltehetően etnikai gazdaságban dolgozott, ez jelentette számukra a munkaerő-piaci integráció lehetőségét. Egy korábbi, surveyre épülő kutatás szintén a vállalkozók kiemelkedően magas arányát mutatta ki ezekben a csoportokban (Örkény - Székelyi 2010).

Ha megnézzük a négy említett származási csoport területi elhelyezkedését, kiderül, hogy átlag feletti (53-89\% közötti) arányban Budapesten éltek. A fővároson belüli térbeli koncentrálódásuk - ami az etnikai enklávék jellegzetessége - azonban kevésbé hangsúlyos. ${ }^{30}$ Más kutatásokból viszont tudjuk, hogy bizonyos gazdasági specializáció (ami a niche-ek ismérve) jellemzi ezeket a vállalkozásokat, amelyek főként kereskedelmi tevékenységet folytatnak (Várhalmi 2013). Többnyire létező piaci keresletet elégítenek ki, és nemcsak a bevándorlók körében.

\section{A MUNKAERŐ-PIACI INTEGRÁCIÓ MAGYARÁZÓ TÉNYEZÖI}

A bevándorlók munkaerő-piaci mutatóinak születési országok szerinti eltéréseit a társadalmi-demográfiai összetételük és területi elhelyezkedésük különbségei mellett feltehetően a Magyarországon töltött idő, továbbá az egyes származási csoportok eltérő nyelvi, kulturális háttere, magyar nyelvismerete, valamint a magyar állampolgársággal való rendelkezése is befolyásolja. ${ }^{31} \mathrm{Az}$ alábbiakban többváltozós elemzéssel vizsgáljuk a felsorolt tényezők hatását a foglalkoztatottság és a túlképzettség esélyére.

A foglalkoztatottság kapcsán első lépésben arra keresünk választ, hogy az aktív korú32 teljes népességen belül a társadalmi-demográfiai összetételre (nem, kor, iskolai végzettség) és a területi elhelyezkedésre (régió, településtípus)

\footnotetext{
30 Mind a négy csoport tagjai szinte kivétel nélkül valamennyi kerületben megtalálhatóak, noha a kínaiak 29\%-a a X. kerületben, 14\%-a a VIII. kerületben élt, a vietnámiak egyötöde szintén a X. kerületben, a szíriaiak egyötöde pedig a XI. kerületben (a törökök három kerületben voltak jelen 10-10\% körüli arányban).

${ }^{31}$ Noha a fogadó ország nyelvének ismerete, valamint állampolgárságának megszerzése önmagukban is integrációs mutatók, számos más területen is befolyásolják az integrációt.

${ }^{32}$ Az elemzést a gazdaságilag aktívabb 25-64 éves korcsoportra szükítettük, akik már zömében befejezték tanulmányaikat (kevesebb mint 5\%-uk tanult, míg a 15-64 éves korcsoport 13\%-a).
} 
kontrollálva hogyan hat a foglalkoztatottság esélyére a külföldi állampolgárság, illetve a külföldi születési hely, valamint a konkrét származási ország. Arra próbálunk választ találni, hogy a bevándorlók magasabb foglalkoztatottsága elsősorban az összetételüknek köszönhetö-e, vagy az összetétel hatását kiszűrve is érvényes marad. Ezt követően a külföldön született népességen belül vizsgáljuk - ugyancsak a társadalmi-demográfiai összetételre és a területi elhelyezkedésre kontrollálva - az érkezés óta eltelt idő, a származási ország, továbbá az állampolgárság (magyar/nem magyar), a nemzetiség (magyar/ nem magyar) és a magyar nyelvismeret hatását. Itt elsősorban arra vagyunk kiváncsiak, hogy a különböző származási csoportok eltérő foglalkoztatottságát mennyire magyarázzák a felsorolt jellemzők szerinti összetételük különbségei, vagy ezektől függetlenül is érvényesülnek-e az országspecifikus sajátosságok.

A foglalkoztatottság esélyét vizsgáló logisztikus regressziós modellekben a függő változónk értéke 1, ha a megkérdezett foglalkoztatott volt, illetve 0 , amennyiben munkanélküli vagy eltartott, de nem tanult. Ezzel a meghatározással az volt a célunk, hogy a rejtett (vagy passziv) munkanélküliséget is megragadjuk, amelyet a bevándorlók - és különösen a bevándorló nők - esetében gyakran az eltartott státus takar. Az elemzésbe bevont magyarázó változók megoszlását a mellékletben lévő M4. táblázat tartalmazza.

Az eredmények alapján a teljes 25-64 éves népességen belül - a társadalmi-demográfiai összetételre és a területi jellemzőkre kontrollálva mind a külföldi állampolgárság, mind a külföldi születési hely szignifikáns, de gyenge hatást mutat: csekély mértékben az előbbi növeli, az utóbbi viszont csökkenti a foglalkoztatottság esélyét (6. táblázat). Ez azt jelenti, hogy a külföldi állampolgárságú, illetve a külföldi születésü népesség magasabb foglalkoztatási rátája valójában az összetételüknek - főként magasabb iskolai végzettségüknek - köszönhető. Ha a külföldi születési hely dummy változója helyett a főbb születési országokat megnevező változót ${ }^{33}$ vonjuk be a modellbe (továbbra is a magyarországi születési helyet tekintve referenciakategóriának), látható, hogy az egyes származási csoportok között - az eltérő összetétel hatását kiszűrve is - jelentős különbségek vannak a foglalkoztatottság esélyét illetően. Főként a kínai és a vietnámi, illetve kisebb mértékben a törökországi születésúek körében nagyobb a foglalkoztatottság esélye, mint a hazai népességben, míg néhány csoport esetében szignifikánsan kisebb (3. modell).

33 Ez a változó a hét legnagyobb származási csoport mellett öt további jellegzetes származási országot is tartalmaz (Vietnám, Törökország, Irán, Szíria és Nigéria), és a tizenkét ország együtt az adott korcsoportba tartozó külföldi születésü népesség 85\%-át fedi le. 
Dekompozíciós eljárás alkalmazásával azonban Károlyi (2016) azt is kimutatta, hogy bár a különbségek nagyobb része magyarázható az összetételkülönbségekkel, az egyes tulajdonságok nem azonos módon járulnak hozzá a csoportok foglalkoztatottságához, továbbá a meg nem figyelt változóknak is jelentős pozitív hatása van a bevándorlók foglalkoztatási előnyére. ${ }^{34}$

6. táblázat: A külföldi állampolgárság, a külföldi születési hely és a származási ország hatása a foglalkoztatottság esélyére a 25-64 éves népességben (logisztikus regressziós modellek esélyhányadosai) The impact of foreign citizenship, foreign birthplace and country of birth on the likelihood of being employed in the population aged 25-64 (the odds ratios of logistic regression models)

\begin{tabular}{|c|c|c|c|c|c|c|c|c|c|}
\hline \multirow{2}{*}{$\begin{array}{l}\text { Magyarázó változók és } \\
\text { kategóriák }\end{array}$} & \multirow{2}{*}{$\begin{array}{c}1 . \\
\text { modell }\end{array}$} & \multirow{2}{*}{2.} & \multirow{2}{*}{$\begin{array}{l}3 . \\
\text { modell }\end{array}$} & \multicolumn{2}{|c|}{ 1A. modell } & \multicolumn{2}{|c|}{ 2A. modell } & \multicolumn{2}{|c|}{ 3A. modell } \\
\hline & & & & férfiak & nők & férfiak & nők & férfiak & nők \\
\hline \multicolumn{10}{|l|}{$\begin{array}{l}\text { Állampolgárság (ref.: } \\
\text { magyar vagy kettős) }\end{array}$} \\
\hline külföldi & $1,079^{* * *}$ & & & $1,550 * * *$ & $0,817^{* * *}$ & & & & \\
\hline \multicolumn{10}{|l|}{$\begin{array}{l}\text { Születési hely } \\
\text { (ref.: Magyarország) }\end{array}$} \\
\hline \multicolumn{10}{|l|}{$\begin{array}{l}\text { Születési ország } \\
\text { (ref.: Magyarország) }\end{array}$} \\
\hline Románia & & & $1,081^{* * *}$ & & & & & $1,277^{* * *}$ & $0,956^{* * *}$ \\
\hline Ukrajna & & & $0,705^{* * *}$ & & & & & $0,892^{* *}$ & $0,620^{* * *}$ \\
\hline Szerbia & & & 0,956 & & & & & $1,081^{*}$ & $0,843^{* * *}$ \\
\hline Szlovákia & & & 1,036 & & & & & $1,289^{* * *}$ & 0,930 \\
\hline Németország & & & $0,856^{* * *}$ & & & & & $1,564^{* * *}$ & $0,589^{* * *}$ \\
\hline Oroszország & & & $0,387^{* * *}$ & & & & & $0,773^{* *}$ & $0,287^{* * *}$ \\
\hline Kína & & & $2,738^{* * *}$ & & & & & $5,132^{* * *}$ & $1,827^{* * *}$ \\
\hline Vietnám & & & $2,344^{* * *}$ & & & & & $2,720^{* * *}$ & $2,107^{* * *}$ \\
\hline Törökország & & & $1,531^{* * *}$ & & & & & $2,403^{* * *}$ & $0,778^{*}$ \\
\hline Irán & & & 1,011 & & & & & 1,065 & 0,963 \\
\hline Szíria & & & $0,708^{* *}$ & & & & & 1,307 & $0,194^{* * *}$ \\
\hline Nigéria & & & $0,738^{*}$ & & & & & $0,609^{* * *}$ & ${ }^{k} 1,288$ \\
\hline egyéb & & & $0,753^{* * *}$ & & & & & 1,047 & $0,552^{* * *}$ \\
\hline Nagelkerke-féle $R^{2}$ & 0,104 & 0,104 & 0,105 & 0,099 & 0,113 & 0,099 & 0,113 & 0,099 & 0,114 \\
\hline
\end{tabular}

Forrás: KSH, 2011. évi népszámlálás. Saját számítás.

Megjegyzés: Kontrollálva a nem, korcsoport, iskolai végzettség, lakóhely régiója és településtípusa változókra. Szignifikanciaszintek: ${ }^{* *}: p<0,001 ;{ }^{* *}: p<0,01 ;{ }^{*}: p<0,05$.

${ }^{34}$ A megfigyelt változók közt azonban a hivatkozott vizsgálatban nem szerepelt az általunk a későbbiekben figyelembe vett érkezési idő, állampolgárság, nemzetiség és magyar nyelvismeret. 
Ha nemek szerinti modellekben vizsgáljuk a fenti tényezők hatását, azt látjuk, hogy mind a külföldi állampolgárság, mind a külföldi születési hely a férfiak foglalkoztatottsági esélyét növeli, a nőkét viszont csökkenti (1A. és 2A. modell). Ez arra utal, hogy a bevándorló nők társadalmi-demográfia összetételüktől és területi elhelyezkedésüktől függetlenül nagyobb eséllyel szorulnak ki a munkaerőpiacról, mind a bevándorló férfiakhoz, mind a nem bevándorló nőkhöz képest még akkor is, ha ezt munkanélküliségi rátájuk nem tükrözi. Ebben a nemek közötti esélykülönbségek mellett bizonyos származási csoportok esetében azoknak a kulturális és társadalmi normáknak, hagyományos nemiszerep-felfogásoknak is szerepük lehet, amelyek behatárolják a nők munkaerő-piaci lehetőségeit, illetve stratégiáit. A születési ország hatását vizsgálva (3A. modell) megállapítható, hogy a külföldi születésű férfiaknak a magyarországi születésủeknél magasabb foglalkoztatottsági esélye nem minden származási csoportra jellemző, másfelől viszont a nők esetében is - noha a csoportok többségében foglalkoztatottsági esélyük elmarad a honos nőkhöz képest - vannak nagyobb eséllyel foglalkoztatott csoportok. (A származási országok szerinti különbségeket a későbbiekben részletesen is tárgyaljuk.)

Mivel az egyes származási csoportok a Magyarországon töltött idő, valamint az állampolgárság és a nyelvismeret szempontjából is eltérő összetételủek, a továbbiakban - az elemzést a külföldön született népességre szükítve - a foglalkoztatottság esélyét magyarázó modellekbe a már említett kontrollváltozók és a származási ország mellé bevonjuk a Magyarországra érkezés óta eltelt időj5 változóját, majd ezt követően külön-külön az állampolgárság, a nemzetiség és a nyelvismeret változóit.

A fogadó országban töltött idő fontos magyarázó tényező, növekedésével a foglalkoztatottság esélye is növekszik: a legfeljebb két éve érkezettekhez képest a 6-10 éve itt élők 60 százalékkal nagyobb eséllyel, a több mint 20 éve itt élők pedig már kétszeres eséllyel voltak foglalkoztatottak (7. táblázat, 4. modell). A származási ország szerinti esélykülönbségek ebben a modellben is jól kirajzolódnak: a referenciakategóriának választott romániai születésú népességhez képest a Kínában születettek foglalkoztatottsági esélye kétszer akkora, a Vietnámban születetteké közel 80 százalékkal, a Szlovákiában születetteké pedig 20 százalékkal nagyobb, ugyanakkor a német, ukrán és szerb csoportoké enyhén, az orosz, nigériai, szíriai és iráni csoportoké jelentős mértékben kisebb volt.

\footnotetext{
35 Mivel az érkezés ideje a külföldi születésủek egy részénél ismeretlen, az elemszámcsökkenés elkerülése érdekében a „nem ismert” kategória is szerepel a változóban.
} 
A kontrollváltozók közül legnagyobb hatása az iskolai végzettségnek van (az alapfokú végzettségủekhez képest a diplomások foglalkoztatottsági esélye közel négyszeres), de jelentős a nemek közötti különbség is: a külföldi születésü nők foglalkoztatottsági esélye mintegy fele a külföldi születésü férfiakénak. ${ }^{36}$ A 25-29 évesekhez képest a 30 és 54 év közötti életkor kissé növeli, az 54 év feletti viszont csökkenti a foglalkoztatottság esélyét.

A nemek szerinti modellben (4A) a származási országok közötti különbségek még élesebben rajzolódnak ki. A Kínából és a Vietnámból származók magasabb foglalkoztatottsági esélye mindkét nemnél megfigyelhető, noha a kínaiak esetében a férfiaknál sokkal hangsúlyosabb. A Szlovákiából származók magasabb foglalkoztatottsági esélye azonban csak a nőknél érvényesül. Ezzel szemben a török származás - bár összességében nem mutatott szignifikáns hatást - a férfiak esetében növelte, a nők esetében viszont csökkentette a foglalkoztatottság esélyét. Hasonlóképpen a szírek alacsonyabb foglalkoztatottsági esélye is csak a nőknél volt szignifikáns és jelentős mértékủ. A szíriai és a török nőknek az azonos országbeli férfiakhoz képest is hátrányosabb foglalkoztatási helyzete mögött sajátos kulturális minták, illetve munkaerőpiaci stratégiák sejthetők, különösen annak fényében, hogy mindkét csoport esetében a férfiak foglalkoztatási aránya jóval átlag feletti, és az etnikai vállalkozások elterjedtsége is jelentős. ${ }^{37}$ Ugyanakkor néhány származási csoport esetében (az oroszországi, az iráni és a nigériai születésüeknél) a foglalkoztatottság esélye mindkét nemnél jelentősen elmarad a honos népességéhez képest.

Az érkezés óta eltelt idő hatása sokkal erőteljesebb a nők esetében, mint a férfiaknál (a több mint 20 éve itt élő nők közel háromszor nagyobb eséllyel foglalkoztatottak, mint az utóbbi két évben érkezettek), ami feltehetően abból adódik, hogy a családi migrációt jellemzően a férfiak munkavállalási lehetősége határozza meg, a nők munkába állására csak idővel kerül sor. A férfiak esetében viszont a felsőfokú végzettség szerepe nagyobb.

\footnotetext{
${ }^{36} \mathrm{~A}$ külföldi születésủ népességben a foglalkoztatottság nemek közötti esélykülönbsége nagyobb, mint a teljes népességben.

${ }^{37}$ Koopmans (2016) vizsgálata is rávilágitott arra, hogy az Európában élő muszlim bevándorlók egyes csoportjainak hátrányos munkaerő-piaci helyzetét főként bizonyos szocio-kulturális jellemzők - többek közt a nemi szerepekkel kapcsolatos értékek - magyarázzák.
} 
7. táblázat: A foglalkoztatottság esélyét magyarázó tényezők a külföldi születésü 25-64 éves népességben (logisztikus regressziós modellek esélyhányadosai)

Factors explaining the likelihood of being employed in the foreign-born population aged 25-64 (the odds ratios of logistic regression models)

\begin{tabular}{|c|c|c|c|c|c|}
\hline \multirow{2}{*}{ Magyarázó változók és kategóriák } & \multirow{2}{*}{ 4. modell } & \multicolumn{2}{|c|}{ 4A. modell } & \multicolumn{2}{|c|}{ 5. modell } \\
\hline & & férfiak & nők & férfiak & nők \\
\hline \multicolumn{6}{|l|}{ Nem (ref.: férfi) } \\
\hline nő & $0,523^{* * *}$ & & & & \\
\hline \multicolumn{6}{|l|}{ Korcsoport (ref.: 25-29) } \\
\hline $30-39$ & $1,185^{* * *}$ & $1,402^{* * *}$ & 1,021 & $1,136^{* *}$ & $1,146^{* * *}$ \\
\hline $40-49$ & $1,207^{* * *}$ & $1,360^{* * *}$ & 1,060 & 0,988 & $1,260^{* * *}$ \\
\hline $50-54$ & $1,115^{* * *}$ & $1,214^{* * *}$ & 0,999 & $0,860^{* *}$ & $1,192^{* * *}$ \\
\hline $55-59$ & $0,937^{*}$ & 1,021 & $0,846^{* * *}$ & $0,705^{* * *}$ & 0,977 \\
\hline $60-64$ & $0,879^{* *}$ & 1,080 & $0,734^{* * *}$ & $0,736^{* * *}$ & $0,847^{*}$ \\
\hline \multicolumn{6}{|l|}{ Iskolai végzettség (ref.: max. 8 általános) } \\
\hline érettségi nélküli középfokú & $1,577^{* * *}$ & $1,618^{* * *}$ & $1,613^{* * *}$ & $1,576^{* * *}$ & $1,543^{* * *}$ \\
\hline érettségi & $2,063^{* * *}$ & $2,133^{* * *}$ & $2,036^{* * *}$ & $2,070^{* * *}$ & $1,892^{* * *}$ \\
\hline felsőfokú & $3,775^{* * *}$ & $4,234^{* * *}$ & $3,586^{* * *}$ & $4,031^{* * *}$ & $3,292^{* * *}$ \\
\hline \multicolumn{6}{|l|}{ Családi állapot (ref.: nőtlen/hajadon) } \\
\hline házas & & & & $1,743^{* * *}$ & $0,789^{* * *}$ \\
\hline élettársi kapcsolatban él & & & & $1,269^{* * *}$ & $0,785^{* * *}$ \\
\hline özvegy & & & & 0,860 & $1,147^{*}$ \\
\hline elvált & & & & $0,889^{*}$ & 1,057 \\
\hline \multicolumn{6}{|l|}{ Gyermekszám (ref.: nincs gyermeke) } \\
\hline egy & & & & $1,152^{* * *}$ & $0,847^{* * *}$ \\
\hline kettő & & & & $1,317^{* * *}$ & $0,830^{* * *}$ \\
\hline három vagy több & & & & $1,144^{* *}$ & $0,558^{* * *}$ \\
\hline \multicolumn{6}{|l|}{$\begin{array}{l}\text { Mióta él Magyarországon (ref.: legtöbb } \\
2 \text { éve) }\end{array}$} \\
\hline $3-5$ éve & $1,334^{* * *}$ & $1,274^{* * *}$ & $1,413^{* * *}$ & $1,235^{* * *}$ & $1,429^{* * *}$ \\
\hline 6-10 éve & $1,608^{* * *}$ & $1,438^{* * *}$ & $1,805^{* * *}$ & $1,347^{* * *}$ & $1,833^{* * *}$ \\
\hline 11-15 éve & $1,616^{* * *}$ & $1,386^{* * *}$ & $1,886^{* * *}$ & $1,310^{* * *}$ & $1,923^{* * *}$ \\
\hline 16-20 éve & $1,760^{* * *}$ & $1,298^{* * *}$ & $2,254^{* * *}$ & $1,257^{* * *}$ & $2,313^{* * *}$ \\
\hline több mint 20 éve & $1,961^{* * *}$ & $1,249^{* * *}$ & $2,809^{* * *}$ & $1,258^{* * *}$ & $2,860^{* * *}$ \\
\hline nem ismert & $6,866^{* * *}$ & $4,758^{* * *}$ & $9,655^{* * *}$ & $5,010^{* * *}$ & $9,449^{* * *}$ \\
\hline \multicolumn{6}{|l|}{ Születési ország (ref.: Románia) } \\
\hline Ukrajna & $0,690^{* * *}$ & $0,644^{* * *}$ & $0,701^{* * *}$ & $0,632^{* * *}$ & $0,700^{* * *}$ \\
\hline Szerbia & $0,862^{* * *}$ & $0,860^{* *}$ & $0,869^{* *}$ & $0,873^{* *}$ & $0,870^{* *}$ \\
\hline Szlovákia & $1,196^{* * *}$ & 1,080 & $1,224^{* * *}$ & 1,123 & $1,232^{* * *}$ \\
\hline Németország & $0,618^{* * *}$ & $0,848^{* *}$ & $0,488^{* * *}$ & 0,900 & $0,491^{* * *}$ \\
\hline Oroszország & $0,388^{* * *}$ & $0,592^{* * *}$ & $0,327^{* * *}$ & $0,603^{* * *}$ & $0,329^{* * *}$ \\
\hline Kina & $1,991^{* * *}$ & $2,773^{* * *}$ & $1,670^{* * *}$ & $2,488^{* * *}$ & $1,778^{* * *}$ \\
\hline Vietnám & $1,769^{* * *}$ & $1,505^{* *}$ & $1,938^{* * *}$ & $1,296^{*}$ & $2,045^{* * *}$ \\
\hline Törökország & 0,910 & $1,390^{*}$ & $0,412^{* * *}$ & $1,364^{*}$ & $0,436^{* * *}$ \\
\hline Irán & $0,530^{* * *}$ & $0,577^{* *}$ & $0,459^{* * *}$ & $0,597^{* *}$ & $0,460^{* * *}$ \\
\hline Szíria & $0,468^{* * *}$ & 0,860 & $0,129^{* * *}$ & 0,833 & $0,149^{* * *}$ \\
\hline Nigéria & $0,408^{* * *}$ & $0,366^{* * *}$ & $0,495^{*}$ & $0,347^{* * *}$ & $0,501^{*}$ \\
\hline egyéb & $0,580^{* * *}$ & $0,671^{* * *}$ & $0,491^{* * *}$ & $0,683^{* * *}$ & $0,500^{* * *}$ \\
\hline Nagelkerke-féle $R^{2}$ & 0,110 & 0,078 & 0,117 & 0.093 & 0,126 \\
\hline
\end{tabular}


A nők munkaerő-piaci integrációját sajátos szempontok (is) alakítják, ezért két további tényező - a családi állapot és a gyermekszám - hatását is megvizsgáltuk (7. táblázat, 5. modell). Látható, hogy a férfiak esetében a házas családi állapot és kisebb mértékben az élettársi kapcsolat is szignifikánsan növelte a foglalkoztatottság esélyét, a nőknél azonban mindkettő csökkentette, és csak az elvált státusz növelte kissé. Továbbá a gyermektelenekhez képest a gyermekes férfiak nagyobb eséllyel dolgoztak, a nőknél viszont a gyermek(ek) - különösen a 3 vagy több gyermek - megléte csökkentette a foglalkoztatottság esélyét. A származási ország szerinti hatásokban e tényezők bevonása nem hozott érdemi változást egyik nemnél sem.

A külföldi születésủ népességben az érkezési idő, illetve a származási ország szerinti különbségek akkor sem változnak, ha - a kontrollváltozók mellett az állampolgárságot (magyar/nem magyar), a nemzetiséget (magyar/nem magyar), valamint a magyar nyelvismeretet is külön-külön figyelembe vesszük. A szomszédos országok esetében (ahonnan jelentős arányban érkeztek magyar nemzetiségủek és a honosítottak aránya is magas) sem módosította érdemben a foglalkoztatottság esélyhányadosait e jellemzők figyelembevétele. Ugyanakkor ezek a jellemzők maguk is szignifikáns hatásokat mutatnak: a magyar állampolgárság megléte 15 százalékkal, a magyar nemzetiség 20 százalékkal, a magyar anyanyelv vagy nyelvismeret pedig közel 60 százalékkal növelte a foglalkoztatottság esélyét (8. táblázat). Bár az állampolgárság megszerzése fontos lépés az integrációs folyamat során, és általános tapasztalat, hogy a honositott bevándorlók foglalkoztatási rátája magasabb, és jobb munkahelyeken dolgoznak, mint a külföldi állampolgárok, az oksági kapcsolat nem mindig egyirányú, hiszen maga a sikeres integráció is növelheti az állampolgárság megszerzésének az esélyét. A fogadó ország nyelvének ismerete többnyire szintén hozzájárul a sikeres integrációhoz, noha az etnikai vállalkozásokban való foglalkoztatottság esetén ez nem feltétlenül szükséges.

A nemek szerinti modellekben látható, hogy a fenti tényezők hatása csak a nők esetében volt szignifikáns, és mindhárom növelte - a magyar állampolgárság 24 százalékkal, a magyar nemzetiség 30 százalékkal, a magyar nyelvismeret pedig több mint kétszeresére - a foglalkoztatottság esélyét. A férfiak esetében feltehetően egyéb, meg nem figyelt tényezők járultak inkább hozzá a foglalkoztatottsághoz, és nagyobb volt köztük a munkavállalási céllal érkezők aránya. 
8. táblázat: Azállampolgárság, a nemzetiség és a magyar nyelvismeret hatása a foglalkoztatottság esélyére a 25-64 éves külföldi születésü népességben (logisztikus regressziós modellek esélyhányadosai)

The impact of citizenship, nationality and language proficiency on the likelihood of being employed in the foreign-born population aged 25-64 (the odds ratios of logistic regression models)

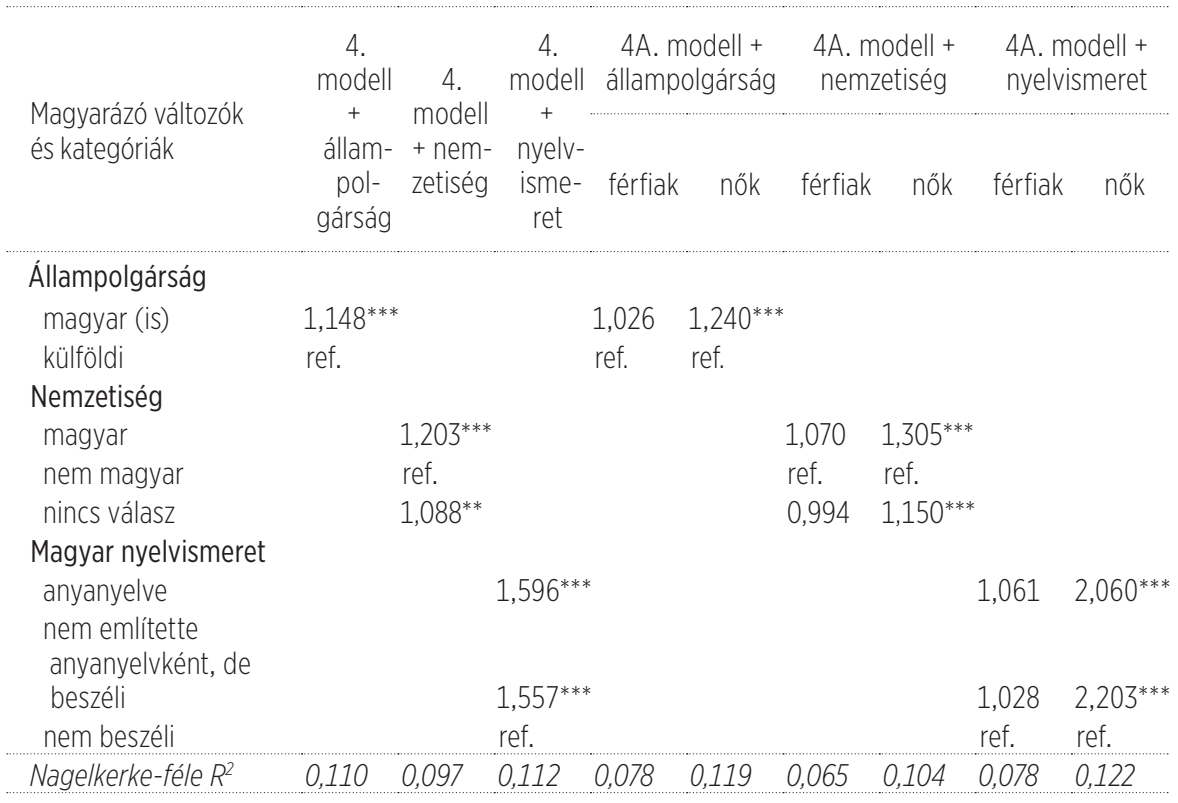

Forrás: KSH, 2011. évi népszámlálás. Saját számítás.

Szignifikanciaszintek: ***: $p<0,001 ;{ }^{* *}: p<0,01 ;{ }^{*}: p<0,05$.

A munkaerő-piaci integráció másik fontos mutatójának, a túlképzettségnek a magyarázó tényezőit vizsgálva a fenti logika alapján, azt látjuk, hogy a teljes 25-64 éves felsőfokú végzettségű magyarországi népességben - nem és kor szerinti összetételre, valamint területi elhelyezkedésre kontrollálva - a külföldi állampolgárság közel 70\%-kal, a külföldi születési hely mintegy 30\%-kal növelte a túlképzettség esélyét (9. táblázat). Ez azonban nem minden származási csoportra jellemző, a születési ország szerinti esélykülönbségek ebben a tekintetben is megmutatkoznak: a kínaiak és különösen a vietnámiak - a diplomások közt is a két legmagasabb foglalkoztatottságú csoport - esetében kiemelkedő a túlképzettség esélye, de a szíriai, a nigériai, a török és az orosz származás is több mint kétszeres esélyt jelent a magyarországi születésűekhez képest. 
A túlképzettség esélyét a külföldi állampolgárság, illetve a külföldi születési hely kissé nagyobb mértékben növeli a nőknél, mint a férfiaknál, és ez a legtöbb származási csoportra érvényes. Ugyanakkor néhány esetben (a török, a nigériai és a kínai születésűeknél) a férfiak túlképzettsége hangsúlyosabb.

9. táblázat: A külföldi állampolgárság, a külföldi szülletési hely és a származási ország hatása a túlképzettség esélyére a 25-64 éves népességben (logisztikus regressziós modellek esélyhányadosai) The impact of foreign citizenship, foreign birthplace and country of birth on the likelihood of overqualification in the population aged 25-64 (the odds ratios of logistic regression models)

\begin{tabular}{|c|c|c|c|c|c|c|c|c|}
\hline \multirow{2}{*}{$\begin{array}{l}\text { Magyarázó } \\
\text { változók és } \\
\text { kategóriák }\end{array}$} & \multirow{2}{*}{$\begin{array}{c}1 . \\
\text { modell }\end{array}$} & \multirow{2}{*}{$\begin{array}{c}2 . \\
\text { modell }\end{array}$} & \multirow{2}{*}{$\begin{array}{c}3 . \\
\text { modell }\end{array}$} & \multicolumn{2}{|c|}{ 1A. modell } & 2A. modell & \multicolumn{2}{|c|}{ 3A. modell } \\
\hline & & & & férfiak & nők & férfiak & férfiak & nők \\
\hline \multicolumn{9}{|l|}{$\begin{array}{l}\text { Állampolgárság } \\
\text { (ref.: magyar } \\
\text { vagy kettős) }\end{array}$} \\
\hline külföldi & $1,683^{* * *}$ & & & $1,590^{* * *}$ & $1,755^{* * *}$ & & & \\
\hline \multicolumn{9}{|c|}{$\begin{array}{l}\text { Születési hely (ref.: } \\
\text { Magyarország) }\end{array}$} \\
\hline külföld & & $1,318^{* * *}$ & & & & $1,204^{* * *} 1,408^{* * *}$ & & \\
\hline \multicolumn{9}{|l|}{$\begin{array}{l}\text { Születési } \\
\text { ország (ref.: } \\
\text { Magyarország) }\end{array}$} \\
\hline Románia & & & 0,998 & & & & $0,887^{* * *}$ & $1,078^{* *}$ \\
\hline Ukrajna & & & $1,444^{* * *}$ & & & & $1,297^{* * *}$ & $1,556^{* * *}$ \\
\hline Szerbia & & & 1,045 & & & & 0,952 & $1,118^{x}$ \\
\hline Szlovákia & & & 0,994 & & & & $0,673^{* * *}$ & $1,251^{* * *}$ \\
\hline Németország & & & 0,948 & & & & $0,776^{* *}$ & $1,159^{x}$ \\
\hline Oroszország & & & $2,071^{* * *}$ & & & & $1,736^{* * *}$ & $2,398^{* * *}$ \\
\hline Kína & & & $6,850^{* * *}$ & & & & $7,611^{* * *}$ & $6,159^{* * *}$ \\
\hline Vietnám & & & $14,431^{* * *}$ & & & & $10,775^{* * *}$ & *22,761*** \\
\hline Törökország & & & $2,396^{* * *}$ & & & & $2,807^{* * *}$ & $1,877^{*}$ \\
\hline Irán & & & 0,907 & & & & 0,948 & 0,848 \\
\hline Szíria & & & $2,785^{* * *}$ & & & & $2,581^{* * *}$ & $3,359^{* *}$ \\
\hline Nigéria & & & $2,639^{* * *}$ & & & & $2,936^{* * *}$ & $1,975^{x}$ \\
\hline egyéb & & & $1,348^{* * *}$ & & & & $1,256^{* * *}$ & $1,506^{* * *}$ \\
\hline Nagelkerke-féle $R^{2}$ & 0,015 & 0,014 & 0,018 & 0,014 & 0,027 & 0,013 & 0,019 & 0,031 \\
\hline
\end{tabular}

Forrás: KSH, 2011. évi népszámlálás. Saját számítás.

Megjegyzés: Kontrollálva a nem, korcsoport, iskolai végzettség, lakóhely régiója és településtípusa változókra. Szignifikanciaszintek: ${ }^{* * *}: p<0,001 ;{ }^{* *}: p<0,01 ; *: p<0,05 ;{ }^{*}: p<0,1$.

A külföldön született népességen belül az érkezés óta eltelt idő hatása nem egyértelmü: a több mint 20 éve itt élőkhöz képest a később érkezők körében ugyan nagyobb a túlképzettség esélye, de nem az utóbbi két évben érkezettek körében a legnagyobb (10. táblázat). Ez mindkét nemnél megfigyelhető, noha az 
érkezés idejének nagyobb szerepe van a nők esetében. A születési ország szerinti különbségekben a már említett tendenciák rajzolódnak ki. A legnagyobb csoporthoz - a romániai születésüekhez - képest a kínai és a vietnami származásúaknál kiugróan magas a túlképzettség esélye, az utóbbiaknál főként a nők esetében.

10. táblázat: A túlképzettség esélyét magyarázó tényezök a külföldi születésü 25-64 éves népességben (logisztikus regressziós modellek esélyhányadosai)

Factors explaining the likelihood of overqualification in the foreign-born population aged 25-64 (the odds ratios of logistic regression models)

\begin{tabular}{|c|c|c|c|}
\hline \multirow{2}{*}{ Magyarázó változók és kategóriák } & \multirow{2}{*}{ 4. modell } & \multicolumn{2}{|c|}{ 4A. modell } \\
\hline & & férfiak & nők \\
\hline \multicolumn{4}{|l|}{ Nem (ref.: férfi) } \\
\hline nő & $1,170^{* * *}$ & & \\
\hline \multicolumn{4}{|l|}{ Korcsoport (ref.: 25-29) } \\
\hline $30-39$ & $0,700^{* * *}$ & $0,787^{* * *}$ & $0,678^{* * *}$ \\
\hline $40-49$ & $0,783^{* * *}$ & 1,017 & $0,670^{* * *}$ \\
\hline $50-54$ & $0,874^{*}$ & 1,166 & $0,713^{* * *}$ \\
\hline $55-59$ & $0,844^{* *}$ & $1,246^{*}$ & $0,594^{* * *}$ \\
\hline $60-64$ & $0,802^{* *}$ & 1,062 & $0,608^{* * *}$ \\
\hline \multicolumn{4}{|l|}{$\begin{array}{l}\text { Mióta él Magyarországon (ref.: } \\
\text { több mint } 20 \text { éve) }\end{array}$} \\
\hline legtöbb 2 éve & $1,237^{* * *}$ & 1,154 & $1,342^{* * *}$ \\
\hline 3-5 éve & $1,426^{* * *}$ & $1,285^{* *}$ & $1,563^{* * *}$ \\
\hline 6-10 éve & $1,418^{* * *}$ & $1,311^{* * *}$ & $1,474^{* * *}$ \\
\hline 11-15 éve & $1,355^{* * *}$ & $1,322^{* * *}$ & $1,345^{* * *}$ \\
\hline 16-20 éve & $1,191^{* *}$ & $1,184^{* *}$ & $1,153^{*}$ \\
\hline nem ismert & 0,937 & 0,995 & $0,877^{*}$ \\
\hline \multicolumn{4}{|l|}{ Születési ország (ref.: Románia) } \\
\hline Ukrajna & $1,428^{* * *}$ & $1,469^{* * *}$ & $1,444^{* * *}$ \\
\hline Szerbia & 1,044 & 1,017 & 1,085 \\
\hline Szlovákia & 0,906 & $0,691^{* *}$ & 1,055 \\
\hline Németország & 0,951 & 0,815 & 1,143 \\
\hline Oroszország & $1,879^{* * *}$ & $1,804^{* * *}$ & $2,027^{* * *}$ \\
\hline Kína & $6,490^{* * *}$ & $7,364^{* * *}$ & $5,722^{* * *}$ \\
\hline Vietnám & $13,583^{* * *}$ & $10,342^{* * *}$ & $20,928^{* * *}$ \\
\hline Törökország & $2,857^{* * *}$ & $3,187^{* * *}$ & $2,256^{*}$ \\
\hline Irán & 1,080 & 1,190 & 0,948 \\
\hline Szíria & $2,919^{* * *}$ & $2,655^{* * *}$ & $3,797^{* *}$ \\
\hline Nigéria & $2,929^{* * *}$ & $3,166^{* * *}$ & $2,264^{x}$ \\
\hline egyéb & $1,336^{* * *}$ & $1,271^{* * *}$ & $1,446^{* * *}$ \\
\hline Nagelkerke-féle $R^{2}$ & 0,076 & 0,086 & 0,077 \\
\hline
\end{tabular}

Forrás: KSH, 2011. évi népszámlálás. Saját számítás.

Megjegyzés: Kontrollálva a lakóhely régiójára és településtípusára is.

Szignifikanciaszintek: ***: $p<0,001 ;{ }^{* *}: p<0,01 ;{ }^{*}: p<0,05 ; x$ : $p<0,1$. 
Míg a teljes népességben a nők túlképzettségi esélye kissé elmaradt a férfiakéhoz képest, a külföldi születésủeknél ennek a fordítottja figyelhető meg, és a korcsoport hatása is gyengébb. A nőknél a 25-29 évesekhez képest valamennyi idősebb korcsoportban kisebb eséllyel fordult elő a túlképzettség, de egyértelmü csökkenő tendenciáról nem beszélhetünk.

Az állampolgárság, a nemzetiség, illetve a magyar nyelvismeret figyelembevételével a származási ország hatása kissé mérséklődik, de az alapvető tendencia megmarad. Ugyanakkor e tényezők maguk is szignifikáns hatásokat mutatnak. A külföldi születésủ népességben a magyar állampolgárság megléte, valamint a magyar nemzetiség csökkenti a túlképzettség esélyét (mintegy 50, illetve 30 százalékkal), közel azonos mértékben a nők és férfiak körében. A magyar nyelvtudás hiánya nem mutat szignifikáns hatást, viszont azok esetében, akik beszélnek ugyan magyarul, de nem az anyanyelvük, 50\%-kal nagyobb a túlképzettség esélye a magyar anyanyelvűekhez képest, és ez a hatás valamelyest hangsúlyosabb a külföldi születésű nők esetében.

\section{ÖSSZEGZÉS}

Tanulmányunkban arra tettünk kísérletet, hogy átfogó képet nyújtsunk a Magyarországon élő bevándorlók integrációjáról a zaragozai indikátorok alapján, majd a legfőbb integrációs terület - a munkaerő-piaci integráció - vonatkozásában részletesen is bemutassuk az integrációs minták sokféleségét, és feltárjuk a főbb mutatók magyarázó tényezőit.

A Magyarországra érkező, illetve itt élő bevándorlók a hazai népességhez képest köztudottan fiatalabbak, magasabb iskolai végzettségủek és munkaerőpiaci helyzetük is jobb. Noha ez általánosságban jellemző a bevándorló népességre, születési országok szerint jelentős heterogenitás figyelhető meg mind a társadalmi-demográfiai összetételük és területi elhelyezkedésük, mind az érkezésük ideje tekintetében, ami az integrációs esélyeiket is meghatározza.

Az áttekintett integrációs mutatók alapján összességében egy munkaerőpiaci szempontból integrálódott, képzettségi mutatóit tekintve sokkal jobb helyzetben lévő, ugyanakkor a túlképzettséget nagyobb arányban megtapasztaló migráns népesség képe rajzolódik ki, amely egészségi állapotát tekintve jobb, lakáshelyzetét tekintve viszont rosszabb helyzetben van, mint a honos népesség. Az integráció vonatkozásában kiemelt figyelmet kapó harmadik országbeli állampolgárok foglalkoztatottsági és képzettségi mutatói is jobbak, mint a teljes népességé, azonban a túlképzettség és a vállalkozók aránya körükben 
mintegy kétszer akkora, ami arra utal, hogy munkaerő-piaci integrációjuk sok esetben az etnikai gazdaságok révén valósul meg, illetve számottevő tudástőkeveszteséggel jár. Bár összességében az EU-tagállamokból származó bevándorlók munkaerő-piaci mutatói jobbak, mint a harmadik országból származóké, e két csoporton belül is jelentős különbségek vannak származási országok szerint.

A Magyarországon élő külföldi állampolgárságú, illetve külföldi születésủ népességnek a hazai népességhez képest magasabb foglalkoztatási rátája kivételnek számít az EU-s országok közt. Magyarázata elsősorban a bevándorlók jellemzőiben keresendő, ugyanis a társadalmi-demográfiai összetételükre és területi elhelyezkedésükre kontrollálva a különbségek jórészt eltűnnek. Ugyanakkor a pozitív összkép jelentős származási országok szerinti különbségeket takar, amelyeket a többváltozós elemzésünk is megerősitett. Továbbá a nemek közötti esélykülönbség is egyértelmủen kimutatható: a külföldi születésủ nők az életkor és iskolai végzettség szerinti összetétel, valamint a területi elhelyezkedés hatását kiszürve is nagyobb eséllyel szorulnak ki a munkaerőpiacról nemcsak a hazai születésú nőkhöz, hanem a külföldi születésú férfiakhoz képest is. Emögött bizonyos származási csoportok esetében a tradicionális női szerepeket elfogadó értékrend, kulturális minták és társadalmi normák, míg más esetekben a migráció motivációival, körülményeivel összefüggő munkaerő-piaci stratégiák sejthetők. A kínai és a vietnámi születésű bevándorlók esetében a nők foglalkoztatottsági esélye is nagyobb a magyarországi születésủekhez képest, nagyon magas viszont a túlképzettek aránya mindkét nemnél, és az etnikai gazdaságban foglalkoztatottak aránya is jelentős. Ezzel szemben a szíriai és a török származású csoportokban - ahol szintén elterjedtek az etnikai vállalkozások - az alacsony foglalkoztatottsági esély csak a nők esetében figyelhető meg.

A bevándorlók társadalmi-demográfiai összetétele és letelepedési helye mellett a Magyarországra érkezés ideje, valamint az állampolgárság, a nemzetiség és a magyar nyelvismeret is meghatározza a munkaerő-piaci integráció esélyeit. A fogadó országban töltött idő növekedésével, a magyar állampolgárság megszerzésével, magyar nemzetiség és anyanyelv esetén, illetve a magyar nyelv elsajátításával a munkaerő-piaci mutatók többnyire javulnak. Mindezen tényezők azonban főként a nők foglalkoztatottsági esélyét növelik, a férfiak esetében hatásuk gyengébb vagy egyáltalán nem érvényesül. A túlképzettség esélyét - mely a társadalmi-demográfiai összetételükre és területi elhelyezkedésükre kontrollálva is nagyobb a bevándorlók körében, mint a hazai népességben - a magyar állampolgárság megszerzése, valamint a magyar nemzetiség és anyanyelv viszont mindkét nem esetében csökkenti. A figyelembe vett magyarázó tényezők azonban a foglalkoztatottság és a túlképzettség származási ország szerinti különbségeit csak részben magyarázzák, az országspecifikus sajátosságok ezek hatását kiszürve is megmaradnak. 


\section{IRODALOM}

Alba, Richard - Nee, Victor 1997: Rethinking Assimilation Theory for a New Era of Immigration. The International Migration Review, 31(4), Special Issue: Immigrant Adaptation and Native-Born Responses in the Making of Americans, 826-874.

Barth, Ernest A. T. - Noel, Donald L. 1972: Conceptual Frameworks for the Analysis of Race Relations: An Evaluation. Social Forces, 50(3), 333-348.

Coleman, David A. 2004: Europe at the cross-roads - Must Europe's population and workforce depend on new migration? International migration: ICPD+10. Scientific Series "International Migration of Population: Russia and Contemporary World", Vol. 12. MAX Press, Moscow, 19-33.

Coleman, David A. 2008: The demographic effects of international migration in Europe. Oxford Review of Economic Policy, 24(3), 452-476.

Demény Pál 2016: Európa két demográfiai válsága: a látható és a fel nem ismert. In Demény Pál: Népességpolitika a közjó szolgálatában, KSH Népességtudományi Kutatóintézet, Budapest, 357-367.

Entzinger, Han - Biezeveld, Renske 2003: Benchmarking in immigrant integration. European Research Centre on Migration and Ethnic Relations (ERCOMER), Rotterdam.

Espenshade, Thomas J. 2001: „Replacement Migration” from the Perspective of Equilibrium Stationary Populations. Population and Environment, 22(4), 383-389.

European Commission 2011: Indicators of Immigrant Integration. A Pilot Study. Eurostat Methodologies \& Working papers. Publications Office of the European Union, Luxembourg. http://ec.europa.eu/eurostat/documents/3888793/5849845/KS-RA-11009-EN.PDF (Letöltve: 2014. 02. 11.)

European Union 2011: Migrants in Europe. A statistical portrait of the first and second generation. Eurostat Statistical books. http://ec.europa.eu/dgs/home-affairs/whatwe-do/policies/pdf/migrants_in_europe_eurostat_2011_en.pdf (Letöltve: 2013. 11. 20.)

European Union 2014: The 2015 Ageing Report. Underlying Assumptions and Projection Methodologies. European Economy 8/2014. European Commission.

Eurostat 2016: Migrant integration statistics - employment. Eurostat Statistics Explained. http://ec.europa.eu/eurostat/statistics-explained/index.php/Migrant_integration_ statistics_-_employment (Letöltve: 2016. 06. 08.)

Gans, Herbert J. 1992: Second-Generation Decline: Scenarios for the Economic and Ethnic Futures of the Post-1965 American Immigrants. Ethnic and Racial Studies, 15(2), 173-192. Gesano, Giuseppe - Strozza, Salvatore 2011: Foreign migrations and population aging in Italy, GENUS, LXVII(3), 83-104.

Gordon, Milton M. 1964: Assimilation in American Life. Oxford University Press, New York. Gödri Irén 2011: Nemek közötti eltérések a külföldi állampolgárok munkaerő-piaci helyzetében Magyarországon. In Nagy Ildikó - Pongrácz Tiborné - Tóth I. György (szerk.): Szerepváltozások. Jelentés a férfiak és a nôk helyzetéről 2011. TÁRKI, Nemzeti Erőforrás Minisztérium, Budapest, 88-112. 
Gödri Irén 2015: Nemzetközi vándorlás. In Monostori Judit - Őri Péter - Spéder Zsolt (szerk.): Demográfiai portré 2015, KSH Népességtudományi Kutatóintézet, Budapest, 187-211.

Gödri Irén 2016: Bevándorlók munkaerő-piaci integrációja Magyarországon - népszámlálási helyzetkép. In Munkaerőpiaci Tükör 2015. MTA Közgazdaság- és Regionális Tudományi Kutatóközpont Közgazdaság-tudományi Intézet, Budapest, 121-134.

Hárs Ágnes 2010: Migráció és munkaerőpiac Magyarországon. Tények, okok, lehetőségek. In Hárs Ágnes - Tóth Judit (szerk.): Változó migráció - változó környezet. MTA Etnikainemzeti Kisebbségkutató Intézet, Budapest, 15-53.

Hárs Ágnes 2013: Túlképzettség és integráció a harmadik országbeli migránsok körében. In Kováts András (szerk.): Bevándorlás és integráció. Magyarországi adatok, európai indikátorok. MTA Társadalomtudományi Kutatóközpont, Kisebbségkutató Intézet, Budapest, 70-88.

Huddleston, Thomas - Niessen, Jan - Tjaden, Jasper D. 2013: Using EU indicators of immigrant integration. Final Report for Directorate-General for Home Affairs. European Commission.

Juhász Judit - Makara Péter - Makara Eszter 2011: A munkaerő-piaci integráció kihivásai Magyarországon - A harmadik országbeli bevándorlók beilleszkedésének esélyei és korlátai. Kutatási Zárótanulmány. Panta Rhei Bt., Budapest.

Károlyi Róbert 2013: Miért jobbak a bevándorlók foglalkoztatási mutatói? In Munkaerőpiaci Tükör 2015, MTA Közgazdaság- és Regionális Tudományi Kutatóközpont Közgazdaságtudományi Intézet, Budapest, 135-137.

Kincses Áron 2015: A nemzetközi migráció Magyarországon és a Kárpát-medence magyar migrációs hálózatai a 21. század elején. KSH Mühelytanulmányok 8. Központi Statisztikai Hivatal, Budapest.

Koopmans, Ruud 2016: Does assimilation work? Sociocultural determinants of labour market participation of European Muslims. Journal of Ethnic and Migration Studies, 42(2), 197-216.

Kováts András 2013: Bevándorlók integrációja Magyarországon korábbi kutatások adatai alapján. In Kováts András (szerk.): Bevándorlás és integráció. Magyarországi adatok, európai indikátorok. MTA Társadalomtudományi Kutatóközpont, Kisebbségkutató Intézet, Budapest, 25-41.

KSH 2015: Az Európai Unión kivüli országok állampolgárai a magyar munkaerőpiacon. Statisztikai tükör, 2015/85.

KSH 2016: 2011. évi népszámlálás. 19. Mühelytanulmányok. Központi Statisztikai Hivatal, Budapest.

Lesthaeghe, Ron 2000: Europe's demographic issues: Fertility, household formation and replacement migration. Expert Group Meeting on Policy Responses to Population Ageing and Population Decline, United Nations Population Division, New York.

Murphy, Michael 2016: The effect of long-term migration dynamics on population structure in England \& Wales and Scotland. Population Studies, 70(2), 1-14.

OECD/European Union 2014: Matching Economic Migration with Labour Market Needs in Europe, Policy Brief. 
OECD/European Union 2015: Indicators of Immigrant Integration 2015: Settling In. OECD Publishing, Paris. http://dx.doi.org/10.1787/9789264234024-en (Letöltve: 2015. 07. 03.)

Örkény Antal - Székelyi Mária 2010: Hat migráns csoport összehasonlító elemzése. In Örkény Antal - Székelyi Mária (szerk.): Az idegen Magyarország - Bevándorlók társadalmi integrációja. ELTE Eötvös Kiadó, MTA Etnikai-nemzeti Kisebbségkutató Intézete, Budapest, 49-96.

Park, Robert E. 1928: Human Migration and the Marginal Man. American Journal of Sociology, 33(6), 881-893.

Piore, Michael J. 1979: Birds of passage: migrant labor and industrial societies. Cambridge University Press, Cambridge.

Portes, Alejandro - Böröcz, József 1989: Contemporary Immigration: Theoretical Perspectives on Its Determinants and Modes of Incorporation. International Migration Review, 23(3), 606-630.

Portes, Alejandro - Manning, Robert D. 2005: The Immigrant Enclave: Theory and Empirical Examples. In Lin, Jan - Mele Christopher (eds.): The Urban Sociology Reader. Routledge, London, 47-68.

Portes, Alejandro - Sensenbrenner, Julia 1993: Embeddedness and Immigration: Notes on the Social Determinants of Economic Action. The American Journal of Sociology, 98(6), 1320-1350.

Portes, Alejandro - Zhou, Min 1993: The New Second Generation: Segmented Assimilation and Its Variants. The Annals of the American Academy of Political and Social Science, 530, 74-96.

Saczuk, Katarzyna 2013: Development and critique the concept of replacement migration. In Kupiszewski, Marek (ed.): International Migration and the Future of Populations and Labour Force Resources in Europe. Springer, 233-242.

Szigel Gábor 2016: Miért ne rettegjünk annyira a demográfiai katasztrófától. http://index.hu/gazdasag/penzbeszel/2016/03/24/miert_ne_rettegjunk_annyira_a_ demografiai_katasztrofatol/ (Letöltve: 2016. 04. 05.)

Turner, Jonathan H. - Bonacich, Edna 2001: A közvetítő kisebbségek összefoglaló elmélete felé. In Sik Endre (szerk.): A migráció szociológiája. Szociális és Családügyi Minisztérium, Budapest, 127-140.

United Nations Population Division 2000: Replacement Migration: Is it a Solution to Declining and Ageing Population? United Nations, New York.

van Nimwegen, Nico - van der Erf, Rob F. 2010: Europe at the Crossroads: Demographic Challenges and International Migration. Journal of Ethnic and Migration Studies, 36(9), 1359-1379.

Várhalmi Zoltán 2013: Vállalkozó migránsok Magyarországon. In Kováts András (szerk.): Bevándorlás és integráció. Magyarországi adatok, európai indikátorok. MTA Társadalomtudományi Kutatóközpont, Kisebbségkutató Intézet, Budapest, 89-100.

Zhou, Min 1997: Segmented Assimilation: Issues, Controversies, and Recent Research on the New Second Generation. International Migration Review, 31(4), 975-1008. 


\section{MELLÉKLET}

M1. táblázat: A külföldi születésü népesség diverzitása a 2001-es és a 2011-es népszámlálás alapján The diversity of foreign-born population based on census 2001 and 2011

\begin{tabular}{crc} 
& 2001 & 2011 \\
\hline A születési országok száma & 192 & 218 \\
a legalább 100 fös csoportok esetében & 58 & 87 \\
a legalább 1000 fős csoportok esetében & 17 & 32 \\
A különböző állampolgárságok száma* & 161 & 167 \\
a legalább 100 fős csoportok esetében & 49 & 74 \\
a legalább 1000 fős csoportok esetében & 12 & 27 \\
Első nemzetiségként a magyart megnevezők aránya (\%) & & \\
a teljes külföldi születésủ népességben & 80,4 & 61,5 \\
a nemzetiségi kérdésre válaszoló külföldi születésű népességben & 87,2 & 83,5
\end{tabular}

Forrás: KSH, 2011. évi népszámlálás. Saját számítás.

a Az első állampolgárság alapján.

M2. táblázat: A 15-64 éves külföldi állampolgárságú, illetve külföldi születésü népesség munkaerőpiaci mutatói nem és korcsoport szerint (\%)

Labour market indicators of foreign citizens and foreign-born population aged 15-64 by gender and age group (\%)

\begin{tabular}{|c|c|c|c|c|c|c|c|c|c|}
\hline \multirow[b]{2}{*}{$\begin{array}{l}\text { Demográfiai } \\
\text { jellemzők }\end{array}$} & \multicolumn{3}{|c|}{ Aktivitási arány } & \multicolumn{3}{|c|}{ Foglalkoztatási ráta } & \multicolumn{3}{|c|}{ Munkanélküliségi ráta } \\
\hline & $\begin{array}{c}\text { külföldi } \\
\text { állam- } \\
\text { polgárok }\end{array}$ & $\begin{array}{c}\text { kül- } \\
\text { földön } \\
\text { született } \\
\text { népesség }\end{array}$ & $\begin{array}{c}\text { teljes } \\
\text { népesség }\end{array}$ & $\begin{array}{c}\text { külföldi } \\
\text { állam- } \\
\text { polgárok }\end{array}$ & $\begin{array}{c}\text { kül- } \\
\text { földön } \\
\text { született } \\
\text { népesség }\end{array}$ & $\begin{array}{c}\text { teljes } \\
\text { népesség }\end{array}$ & $\begin{array}{c}\text { külföldi } \\
\text { állam- } \\
\text { polgárok }\end{array}$ & $\begin{array}{c}\text { kül- } \\
\text { földön } \\
\text { született } \\
\text { népesség }\end{array}$ & $\begin{array}{c}\text { teljes } \\
\text { népesség }\end{array}$ \\
\hline \multicolumn{10}{|l|}{ Nem } \\
\hline férfi & 73,9 & 78,3 & 70,5 & 69,6 & 72,1 & 61,5 & 5,8 & 7,9 & 12,8 \\
\hline nő & 59,5 & 65,8 & 60,2 & 55,2 & 59,6 & 52,6 & 7,2 & 9,4 & 12,7 \\
\hline \multicolumn{10}{|l|}{ Korcsoport } \\
\hline 15-19 & 8,4 & 7,4 & 4,9 & 7,3 & 6,4 & 3,3 & 12,8 & 13,7 & 32,5 \\
\hline $20-24$ & 41,5 & 45,7 & 52,5 & 37,5 & 39,3 & 40,8 & 9,4 & 14,0 & 22,3 \\
\hline $25-29$ & 72,1 & 76,5 & 81,9 & 67,3 & 69,1 & 69,3 & 6,7 & 9,7 & 15,4 \\
\hline $30-39$ & 82,3 & 83,1 & 84,2 & 77,2 & 76,3 & 74,3 & 6,2 & 8,2 & 11,8 \\
\hline $40-49$ & 85,9 & 89,4 & 86,9 & 80,8 & 82,3 & 77,1 & 6,0 & 8,0 & 11,3 \\
\hline $50-54$ & 78,8 & 83,9 & 80,0 & 74,3 & 76,9 & 71,0 & 5,7 & 8,3 & 11,3 \\
\hline $55-59$ & 62,4 & 69,8 & 61,1 & 58,4 & 63,6 & 54,2 & 6,5 & 8,9 & 11,3 \\
\hline $60-64$ & 23,8 & 25,9 & 17,7 & 22,8 & 24,3 & 16,5 & 4,1 & 6,1 & 6,9 \\
\hline Együtt & 66,7 & 71,7 & 65,3 & 62,4 & 65,5 & 57,0 & 6,5 & 8,7 & 12,7 \\
\hline
\end{tabular}

Megjegyzés: A 30-34 és 35-39, valamint a 40-44 és 45-49 éves korcsoportokat a közel azonos mutatók miatt összevontuk. 
M3. táblázat: A 25-64 éves külföldi állampolgárságú, illetve külföldi születésü népesség munkaerőpiaci mutatói iskolai végzettség szerint (\%)

Labour market indicators of foreign citizens and foreign-born population aged 25-64 by level of education (\%)

\begin{tabular}{|c|c|c|c|c|c|c|c|c|c|}
\hline \multirow[b]{2}{*}{$\begin{array}{l}\text { Iskolai } \\
\text { végzettség }\end{array}$} & \multicolumn{3}{|c|}{ Aktivitási arány } & \multicolumn{3}{|c|}{ Foglalkoztatási ráta } & \multicolumn{3}{|c|}{ Munkanélküliségi ráta } \\
\hline & $\begin{array}{c}\text { külföldi } \\
\text { állam- } \\
\text { polgárok }\end{array}$ & $\begin{array}{c}\text { kül- } \\
\text { földön } \\
\text { született } \\
\text { népesség }\end{array}$ & $\begin{array}{c}\text { teljes } \\
\text { népesség }\end{array}$ & $\begin{array}{c}\text { külföldi } \\
\text { állam- } \\
\text { polgárok }\end{array}$ & $\begin{array}{c}\text { kül- } \\
\text { földön } \\
\text { született } \\
\text { népesség }\end{array}$ & $\begin{array}{c}\text { teljes } \\
\text { népesség }\end{array}$ & $\begin{array}{c}\text { külff̈ldi } \\
\text { állam- } \\
\text { polgárok }\end{array}$ & $\begin{array}{c}\text { kül- } \\
\text { földön } \\
\text { született } \\
\text { népesség }\end{array}$ & $\begin{array}{c}\text { teljes } \\
\text { népesség }\end{array}$ \\
\hline $\begin{array}{l}8 \text { általános } \\
\text { alatt }\end{array}$ & 53,6 & 50,6 & 29,9 & 48,0 & 43,6 & 16,7 & 10,5 & 14,0 & 44,2 \\
\hline $\begin{array}{l}8 \text { általános } \\
\text { Érettségi } \\
\text { nélküli }\end{array}$ & 65,3 & 65,0 & 54,5 & 58,5 & 56,1 & 40,8 & 10,4 & 13,7 & 25,3 \\
\hline középfokú & 77,1 & 78,9 & 75,3 & 71,7 & 70,9 & 65,0 & 7,0 & 10,1 & 13,7 \\
\hline Érettségi & 74,9 & 78,3 & 76,6 & 70,4 & 71,5 & 69,4 & 6,0 & 8,8 & 9,4 \\
\hline Felsőfokú & 79,6 & 82,4 & 83,7 & 76,6 & 78,2 & 79,6 & 3,7 & 5,1 & 4,9 \\
\hline Együtt & 74,8 & 77,8 & 73,1 & 70,2 & 71,4 & 64,4 & 6,1 & 8,3 & 11,8 \\
\hline
\end{tabular}

Forrás: KSH, 2011. évi népszámlálás. Saját számítás. 
M4. táblázat: A logisztikus regressziós elemzésben szereplő változók megoszlása a 25-64 éves teljes népességben, illetve külföldi születésü népességben (\%)

Distribution of variables included in logistic regression analyses in total population and foreign-born population aged 25-64 (\%)

\begin{tabular}{|c|c|c|c|c|}
\hline \multirow{2}{*}{ Változók } & \multirow{2}{*}{$\begin{array}{c}\text { Teljes } \\
\text { népesség }\end{array}$} & \multicolumn{3}{|c|}{ Külföldön született népesség } \\
\hline & & összesen & férfiak & nők \\
\hline \multicolumn{5}{|l|}{ Nem } \\
\hline férfi & 49,0 & 46,6 & & \\
\hline nő & 51,0 & 53,4 & & \\
\hline \multicolumn{5}{|l|}{ Korcsoport } \\
\hline $25-29$ & 10,0 & 10,6 & 10,4 & 10,8 \\
\hline $30-39$ & 27,9 & 30,3 & 30,8 & 30,0 \\
\hline $40-49$ & 23,8 & 28,2 & 29,5 & 27,0 \\
\hline $50-54$ & 12,0 & 11,2 & 11,0 & 11,5 \\
\hline $55-59$ & 14,3 & 10,6 & 9,9 & 11,1 \\
\hline $60-64$ & 12,0 & 9,1 & 8,4 & 9,6 \\
\hline \multicolumn{5}{|l|}{ Iskolai végzettség } \\
\hline max. 8 általános & 19,3 & 12,9 & 11,4 & 14,2 \\
\hline érettségi nélküli középfokú & 29,3 & 21,1 & 26,7 & 16,2 \\
\hline érettségi & 31,0 & 35,4 & 31,5 & 38,7 \\
\hline felsőfokú & 20,4 & 30,6 & 30,4 & 30,9 \\
\hline \multicolumn{5}{|l|}{ Településtípus } \\
\hline Budapest & 17,4 & 33,9 & 34,1 & 33,8 \\
\hline város & 52,1 & 42,6 & 42,4 & 42,8 \\
\hline község & 30,5 & 23,5 & 23,5 & 23,5 \\
\hline \multicolumn{5}{|l|}{ Régió } \\
\hline Közép-Magyarország & 29,6 & 50,6 & 50,8 & 50,5 \\
\hline Közép-Dunántúl & 11,1 & 8,2 & 8,0 & 8,4 \\
\hline Nyugat-Dunántúl & 10,3 & 7,7 & 7,9 & 7,5 \\
\hline Dél-Dunántúl & 9,4 & 6,3 & 6,4 & 6,1 \\
\hline Észak-Magyarország & 11,8 & 5,1 & 4,8 & 5,3 \\
\hline Észak-Alföld & 14,8 & 10,3 & 9,7 & 10,8 \\
\hline Dél-Alföld & 13,0 & 11,8 & 12,3 & 11,4 \\
\hline \multicolumn{5}{|l|}{ Családi állapot } \\
\hline nőtlen/hajadon & 17,8 & 13,2 & 16,7 & 10,2 \\
\hline házas & 53,5 & 61,0 & 60,2 & 61,7 \\
\hline élettársi kapcsolatban él & 13,8 & 14,8 & 16,2 & 13,5 \\
\hline özvegy & 4,3 & 2,7 & 0,9 & 4,4 \\
\hline elvált & 10,6 & 8,3 & 6,1 & 10,2 \\
\hline \multicolumn{5}{|l|}{ Gyermekszám } \\
\hline nincs gyermeke & 24,8 & 25,9 & 31,0 & 21,3 \\
\hline egy & 23,1 & 30,3 & 28,4 & 32,0 \\
\hline kettő & 36,3 & 32,1 & 29,3 & 34,6 \\
\hline három vagy több & 15,9 & 11,7 & 11,3 & 12,1 \\
\hline
\end{tabular}

Forrás: KSH, 2011. évi népszámlálás. 
M4. táblázat: A logisztikus regressziós elemzésben szereplő változók megoszlása a 25-64 éves teljes népességben, illetve külföldi születésü népességben (\%) (folytatás)

Distribution of variables included in logistic regression analyses in total population and foreign-born population aged 25-64 (\%) (continued)

\begin{tabular}{|c|c|c|c|c|}
\hline \multirow{2}{*}{ Változók } & \multirow{2}{*}{$\begin{array}{c}\text { Teljes } \\
\text { népesség }\end{array}$} & \multicolumn{3}{|c|}{ Külföldön született népesség } \\
\hline & & összesen & férfiak & nők \\
\hline \multicolumn{5}{|l|}{ Mióta él Magyarországon } \\
\hline legtöbb 2 éve & & 7,3 & 8,5 & 6,2 \\
\hline 3-5 éve & & 6,8 & 7,2 & 6,5 \\
\hline 6-10 éve & & 12,1 & 11,6 & 12,5 \\
\hline 11-15 éve & & 12,5 & 12,4 & 12,7 \\
\hline 16-20 éve & & 14,9 & 14,6 & 15,1 \\
\hline több mint 20 éve & & 26,9 & 25,5 & 28,2 \\
\hline nem élt legalább egy évet külföldön & & 5,2 & 5,2 & 5,1 \\
\hline nem ismert & & 14,3 & 15,0 & 13,7 \\
\hline \multicolumn{5}{|l|}{ Születési ország } \\
\hline Románia & & 51,4 & 50,5 & 52,3 \\
\hline Ukrajna & & 9,8 & 7,8 & 11,5 \\
\hline Szerbia & & 6,9 & 8,1 & 5,9 \\
\hline Szlovákia & & 4,4 & 3,3 & 5,3 \\
\hline Németország & & 5,5 & 5,4 & 5,6 \\
\hline Oroszország & & 2,0 & 1,3 & 2,6 \\
\hline Kína & & 2,9 & 3,2 & 2,6 \\
\hline Vietnám & & 0,9 & 1,0 & 0,8 \\
\hline Törökország & & 0,5 & 0,8 & 0,3 \\
\hline Irán & & 0,4 & 0,5 & 0,3 \\
\hline Szíria & & 0,3 & 0,5 & 0,2 \\
\hline Nigéria & & 0,3 & 0,4 & 0,2 \\
\hline egyéb & & 14,7 & 17,3 & 12,4 \\
\hline \multicolumn{5}{|l|}{ Állampolgárság } \\
\hline magyar (is) & & 61,2 & 58,6 & 63,5 \\
\hline külföldi & & 38,8 & 41,4 & 36,5 \\
\hline \multicolumn{5}{|l|}{ Nemzetiség } \\
\hline magyar & & 70,7 & 68,1 & 73,0 \\
\hline nem magyar & & 16,4 & 18,1 & 14,9 \\
\hline nincs válasz & & 12,9 & 13,8 & 12,1 \\
\hline \multicolumn{5}{|l|}{ Magyar nyelvismeret } \\
\hline anyanyelve & & 57,6 & 55,2 & 59,7 \\
\hline nem emlitette anyanyelvként, de beszéli & & 36,9 & 38,1 & 35,9 \\
\hline nem beszéli & & 5,5 & 6,7 & 4,4 \\
\hline N & 5436996 & 219472 & 102218 & 117254 \\
\hline
\end{tabular}

Forrás: KSH, 2011. évi népszámlálás. 


\section{INTEGRATION OF IMMIGRANTS IN HUNGARY}

\section{ABSTRACT}

This study investigates the integration of immigrants in Hungary based on data from the 2011 Population Census, with particular emphasis on their labour market integration. We distinguish between foreign citizens and foreign-born population, revealing the heterogeneity of different groups of origin. Based on the Zaragoza indicators adopted in 2010, the study provides a general overview of the situation of immigrants in the main areas of integration (employment, education, health status and housing). Then we analyse in detail the main indicators of labour market integration (employment, unemployment, overqualification and self-employment) by sociodemographic characteristics and the country of birth of immigrants. Moreover, based on multivariable analyses, we present the factors explaining the likelihood of being employed and of overqualified in the foreign-born population. The findings indicate that the higher employment rate of the foreign citizens and foreign-born population in Hungary are in fact due to their composition and territorial distribution, but important differences by country of origin and time of arrival are detected, and gender differences are also revealed. Holding Hungarian citizenship, the Hungarian ethnicity and Hungarian language skills increase the employment probability for women, and decrease the overqualification probability for both sexes. 